Başar, T. ve Yavaşlı, M. (2020). Yazarlık ve yazma becerileri dersi öğretim programı́na yönelik öğretmen görüşleri. Ana Dili Eğitimi Dergisi, 8(2), 270-291.

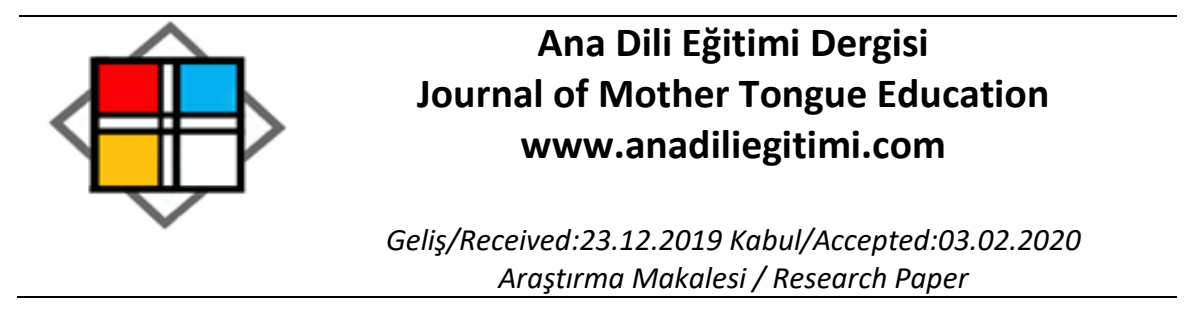

\title{
Yazarlık ve Yazma Becerileri Dersi Öğretim Programı'nın Öğretmen Görüşleri Doğrultusunda Değerlendirilmesi
}

\author{
Tarık BAŞAR ${ }^{* *}$ \\ Meral YAVAŞLI**
}

\begin{abstract}
Öz
Bu araştırma, 2018 Yazarlık ve Yazma Becerileri Dersi Öğretim Programı́nı öğretmen görüşleri doğrultusunda değerlendirmek amacıyla gerçekleştirilmiştir. Bu amaç doğrultusunda araştırma modeli, nitel araştırma yöntemlerinden birisi olan durum çalışması olarak tasarlanmıştır. Araştırmanın çalışma grubunu ise maksimum çeşitlilik örnekleme yöntemiyle belirlenen on beş Türkçe öğretmeni oluşturmaktadır. Araştırmada, veri toplama aracı olarak yarı yapılandırılmış bir görüşme formu kullanıımıştır. Araştırmada elde edilen verilerin analizinde ise içerik analizi yönteminden yararlanılmıştır. Araştırma sonucunda, programda yaratıcılığa gereken önemin verilmediği, öğretmenlerin programı uygularken teknolojiden çok fazla yararlanmadıkları ve daha çok sonuç odaklı değerlendirme yöntemlerini tercih ettikleri belirlenmiştir. Ayrıca öğretmenler, mevcut sınav sistemi, öğrencilerin okuma alışkanlığının olmayışı ve öğrencilerin yazma etkinliklerine yönelik istek ve motivasyonlarının düşük olması gibi nedenlerden dolayı uygulamada sorunlar yaşadıklarını belirtmiştir.
\end{abstract}

Anahtar Kelimeler: Yazarlık ve yazma becerileri dersi öğretim programı, yazma becerisi, yazıı anlatım

\section{Evaluation of Authorship and Writing Skills Course Curriculum in line with the Opinions of Teachers}

\begin{abstract}
This research was carried out to evaluate the 2018 Authorship and Writing Skills Curriculum in line with the opinions of teachers. For this purpose, the research model was designed as a case study, which is one of the qualitative research methods. The study group of the research consists of fifteen Turkish teachers determined by maximum variation sampling method. In the research, a semi-structured interview form was used as a data collection tool. Content analysis method was used in the analysis of the data obtained in the research. As a result of the research, it was determined that creativity was not given importance in the curriculum, teachers did not use technology much while implementing the curriculum and they preferred more result-based evaluation methods. In addition, the teachers stated that they had problems in practice due to the existing examination system, absence of reading habits of their students and low wanting and motivation towards writing activities.
\end{abstract}

Keywords: Authorship and writing skills course curriculum, writing skill, written expression

\section{Giriş}

Eğitim programları aracılığıyla öğrencilere kazandırılmak istenilen bilgi ve beceri alanlarından birisi de dil eğitimidir (Calp, 2010). Dil eğitimi ise "konuşma, dinleme, okuma ve yazma" olmak üzere

\footnotetext{
** Dr. Öğr. Üyesi, Kırşehir Ahi Evran Üniversitesi, Eğitim Fakültesi, Eğitim Bilimleri Bölümü, Kırşehir, tarik.basar@ahievran.edu.tr, ORCID: 0000-0002-2653-0435

*** Yüksek Lisans Öğrencisi, Kırşehir Ahi Evran Üniversitesi, Eğitim Fakültesi, Eğitim Bilimleri Bölümü, Kırşehir, meralyavasli@gmail.com, ORCID: 0000-0003-0276-9561
} 
dört temel beceri alanını içermektedir. Bu beceri alanlarından dinleme, bireyin yaşamında kazandığı ilk beceridir ve bu beceriyi de konuşma becerisi takip etmektedir (Kasten ve Yıldırım, 2013). Günlük yaşamda eş zamanlı kullanılan dinleme ve konuşma becerileri birbirleriyle ilişkili iki beceridir (Sadiku, 2015). Konuşma becerisi aynı zamanda okuma ve yazma gibi diğer iki temel becerinin de özünü oluşturmaktadır (Aktaş ve Gündüz, 2015).

Okuma ve yazma becerilerinin ise birbirlerinden etkilenen iki beceri olduğu kabul edilen bir gerçektir (Oshchepkova ve Alkhaldi, 2018). Yani bu iki beceri birbirinden bağımsız düşünülemez. Yazma eğitimi alanında yapılan çalışmaların akademik eğilimlerini inceleyen ve yapılan 50 tez çalışmasında yazma becerisinin okuma becerisiyle ilişkilendirildiği sonucuna ulaşan Tok ve Potur (2015) da yaptıkları çalışma ile bu görüşü doğrulamaktadır.

Okuma ve yazma becerilerini, dinleme ve konuşma becerilerinden ayıran en önemli nokta ise bu iki becerinin kazanılması ve daha sonra da geliştirilmesi süreçlerinin eğitim aracılığıyla sağlanmasıdır. Oysaki dinleme ve konuşma becerileri eğitim aracılı̆ı̀la geliştirilebilen beceriler olmasına rağmen eğitim almadan da kazanılmaktadır (Karakoç Öztürk, 2012). Karatay’a (2011) göre, bu dört temel dil becerisi içinde geliştirilmesi için daha fazla zamana ihtiyaç duyulan beceri ise yazma becerisidir. Dolayısıyla da yazma becerisi, kısa zamanda kazanılacak kolay bir beceri değildir (Özonat ve Sis, 2016).

Yazma becerisini bireyin duygu veya düşüncelerini ifade etmede belli sembol ve işaretleri düzenleme ve kullanma becerisi olarak tanımlamak mümkündür. Yazma becerisi, el ve göz eğitimi sonucunda kazanılan ve aynı zamanda çaba ve deneyim gerektiren bir beceridir (Gündüz ve Şimşek, 2016). Ayrıca yazma becerisi bilişsel boyutu da olan bir beceridir ve bu kapsamda bilgi, kavrama, uygulama ve sentez gibi bilişsel alan basamaklarını da içermektedir (Defazio, Jones, Tennant ve Hook, 2010). Zaten yazma becerisinin en önemli özelliklerinden birisi de düşünmeyi içermesidir. Yazma becerisinin bir diğer özelliği ise bireyin duygu ve düşüncelerini kalıcı olarak ifade emesine imkan vermesidir (Yakıcı, Yücel, Doğan ve Yelok, 2006).

Bireylerin yaşamlarının her alanında ihtiyaç duyacakları bu beceriyi kazanabilmeleri ve günlük yaşamlarında etkili olarak kullanabilmeleri ise ilkokul ve ortaokul düzeyinde alacakları eğitime bağlıdır (Bahşi ve Sis, 2019). Öğrencilerin yazma becerisine yönelik alacakları eğitim ise onların hem Türkçe hem de diğer derslerdeki başarılarını da etkileyecektir. Alan yazında yapılan çalışmalar da bu görüşü doğrulamaktadır. Temur (2001) 5. sınıf öğrencileriyle yaptığı çalışmada, öğrencilerin yazma becerileri ile okul başarıları arasında anlamlı bir ilişki olduğunu belirlerken Kaleağası (2009) ise 4. ve 5. sınıf öğrencileriyle yaptığı çalışmada, yazma becerileri ile öğrencilerin Türkçe dersi başarıları arasında anlamlı bir ilişki olduğunu belirlemiştir. Yani öğrencilerin eğitim yaşamlarında başarılı olmaları yazma becerilerindeki yeterliliklerine bağlıdır (Durga ve Rao, 2018). Fakat bireyin yaşamında önemli bir yere sahip olan yazma becerisinde öğrenciler okul hayatları boyunca zorluk yaşamaktadır (Tok ve Ünlü, 2014). Deniz (2017) tarafından yapılan çalışma da bu görüşü desteklemektedir. Deniz (2017) tarafından 7. sınıf öğrencileriyle yapılan çalışmada, öğrencilerin yazma becerisi düzeylerinin yetersiz olduğu tespit edilmiştir.

Öğrencilerin yazma becerisinde zorluk yaşamalarının nedeni ise yazma becerisinin kolay kazandırılacak bir beceri olmamasından kaynaklanmaktadır (Afrin, 2014). Ayrıca yazma becerisi kazanma sürecinde karşılaşılan birçok sorun da süreci olumsuz etkilemektedir. Tok ve Ünlü (2014) ortaokul düzeyinde yazma becerisi kazanma sürecini olumsuz etkileyen bu sorunları öğretmenden kaynaklı, öğrenciden kaynaklı, eğitim sisteminden kaynaklı ve diğer olmak üzere dört başlık altında incelemiştir. Öğretmenden kaynaklı sorunların başında öğretmenlerin yazma becerisine yönelik yeterli donanıma sahip olmaması; öğrenciden kaynaklı sorunların başında ise okuma alışkanlığının olmaması gelmektedir. Ayrıca eğitim sisteminden kaynaklı sorunun ulusal sınav sisteminden ve diğer başlığı altında yer alan sorunun ise televizyon ve internetin olumsuz etkilerinden kaynaklandığı belirlenmiştir. Tağa ve Ünlü (2013) ise yaptıkları benzer bir çalışmada yazma becerisi kazanma sürecini olumsuz etkileyen sorunları öğrenciden kaynaklı, öğretmenden kaynaklı, programdan kaynaklı ve dış etkenlerden kaynaklı olmak üzere dört kategoriye ayırmıştır. Öğrenciden kaynaklı sorunların başında okuma alışkanlığının olmayışı, öğretmenden kaynaklı sorunların başında alandaki güncel çalışmaların 
takip edilmeyişi; programdan kaynaklı sorunların başında süre yetersizliği ve dış etkenlerden kaynaklı sorunların başında ise internet ve cep telefonlarında kullanılan dil gelmektedir.

Öğrencilerin yazma etkinliklerinde yaşadıkları zorluk ise yazma becerisine yönelik olumsuz tutumlar geliştirmelerine neden olmaktadır (Yaman, 2010). Ayrıca bu zorluk öğrencilerin yazma etkinliklerinden kaçınmalarına da yol açmaktadır (Ungan, 2007). Baş ve Şahin (2013) tarafından yapılan çalışma da bu görüşü doğrulamaktadır. Baş ve Şahin (2013) yaptıkları çalışmada, ilköğretim öğrencilerinin yazma eğilim algılarının düşük olduğu sonucuna ulaşmıştır.

Kısacası yazma becerisi, öğrencilerin kazanmakta zorlandıkları bir beceridir (Younes ve Albalawi, 2015). Öğrencilerin sorun yaşadıkları bu beceri alanının daha etkin kazandırılması ve öğrencilerin yazma etkinliklerinden zevk almalarını sağlamak amacıyla ise Türkiye'de yazma becerine yönelik Türkçe dersinden bağımsız "Yazarlık ve Yazma Becerileri" adı altında yeni bir dersin oluşturulmasına karar verilmiştir. Bu yeni derse yönelik ilk program ise 2012 yılında yayınlanmıştır. Seçmeli olarak uygulanan bu ders ortaokul 5, 6, 7 ve 8. sınıf düzeylerini kapsamaktadır. 2012 Yazarlık ve Yazma Becerileri Dersi Öğretim Programı ise "Her öğrenci duygu ve düşüncesini yazılı olarak ifade etme yeteneğine sahiptir" görüşü temel alınarak hazırlanmıştır (Milli Eğitim Bakanlığı, 2012).

2012 YYB programında yazma becerisinin güzel ve etkili olabilmesi için zamana ihtiyaç olduğu da belirtilmiştir. Bu doğrultuda, 2012 YYB programında öğretim yaklaşımı olarak süreç temelli yaklaşım benimsenmiştir. 2012 programında yazma becerisine yönelik beş beceri ve bu becerilere ait kazanımlar yer almaktadır. 2012 YYB programının en önemli özelliği ise belirlenen beceri ve kazanımlara ulaşmada öğretmenlere yol gösterecek öğretim programı uygulama kılavuzunu da içermesidir. Bu kılavuzda, YYB programında belirlenen beceri ve kazanımlar için "başlangıç düzeyinde", "orta düzeyde", "yeterli düzeyde" ve "ileri düzeyde" olmak üzere dört farklı düzey belirlenmiştir. 2012 YYB programında yer alan bu düzeyler, öğrencilerin öğrenim gördükleri sınıf düzeyleri veya YYB dersini kaçıncı kez seçtiklerine göre değil; öğrencilerin yazma becerilerinin düzeyleri esas alınarak belirlenmiştir. YYB programı uygulama kılavuzunda, her bir kazanıma öğrencilerin ulaşabilmesi için dört temel düzeyin her birinde yapılabilecek etkinlik örnekleri de yer almaktadır. Dolayısıyla 2012 YYB programında, öğretmenlerden istenilen yazma becerine yönelik gerçekleştireceği etkinlikleri öğrencilerinin düzeylerine uygun olarak gerçekleştirmesidir (MEB, 2012).

2018 yılında ise 2012 YYB dersi öğretim programında değişikliklere gidilerek program yeniden güncellenmiş ve 2018 YYB dersi öğretim programı hazırlanmıştır. Yapılan bu çalışmada da 2018 programı esas alınmıştır. 2018 YYB programında, 2012 YYB programında olduğu gibi yazma becerisi bir süreç olarak görülmektedir. Yani yazma becerisine yönelik yapılacak etkinliklerde temel amaç, ürün odaklı geleneksel yaklaşımlardaki gibi yazılı anlatım çalışmaları meydana getirmek değil; öğrencilerin yazma sürecindeki sorumluluğu kendilerinin alarak süreci kendi başlarına gerçekleştirebilme becerisi kazandırmaktır (MEB, 2018).

2018 YYB programı 2012 YYB programından farlı olarak yeterlilik temelli hazırlanmış ve bu kapsamda programda "hazırlık", "planlama", "geliştirme", "düzeltme" ve "sunum" olmak üzere beş yeterlilik belirlenmiştir. 2018 YYB programında her bir yeterlilik için de öğrencilerin ulaşması gereken kazanımlar yer almaktadır. 2018 YYB programında yer alan yeterliliklerin sıralaması ve bu yeterlilikler için belirlenen kazanım sayıları ve öngörülen ders saatleri aşağıdaki Tablo 1'de verilmiştir (MEB, 2018):

Tablo 1.

2018 YYB programında yer alan yeterlilik adları, kazanım sayıları ve öngörülen ders saatleri

\begin{tabular}{cccc}
\hline Yeterlilik Sırası & Yeterlilik Adı & Kazanım Sayısı & Ders Saati \\
\hline 1 & Hazırlık & 8 & 19 \\
2 & Planlama & 4 & 9 \\
3 & Geliştirme & 8 & 19 \\
4 & Düzeltme & 6 & 14 \\
5 & Sunum & 5 & 11 \\
Toplam & & 31 & 72 \\
\hline
\end{tabular}


2018 YYB programında yer alan yeterlilikler ve kazanımlar tüm sınıf düzeylerinde aynıdır. Bu kapsamda, 2018 YYB programında "Öğretim programının uygulanmasında dikkat edilecek hususlar" başlığı altında hangi sınıf düzeyinde ne tür etkinliklerin yapılabileceğine yönelik önerilere yer verilmiştir. Örneğin; beşinci sınıflarda 6-8 kelimelik cümleler içeren etkinlikler önerilirken; yedinci ve sekizinci sınıflar için on iki ve üzeri kelimelik cümleler içeren etkinliklerin yapılması önerilmiştir. Yine benzer şekilde beşinci sınıflar için öyküleyici anlatım metinlerine yönelik etkinliklerin yapılabileceği belirtilirken; yedinci ve sekizinci sınıflarda bilimsel yazma etkinliklerine yer verilebileceği ifade edilmiştir. Yani öğretmenlerden beklenilen, sınıflarda yazma becerisine yönelik yapacakları etkinlikleri öğrencilerin gelişim düzeylerine uygun olarak gerçekleştirmeleridir.

2018 YYB programını 2012 YYB programından ayıran en temel fark ise 2012 YYB programında yer alan program uygulama kılavuzunun 2018 YYB programında yer almamasıdır. Yani 2018 YYB programında, 2012 YYB programında her bir kazanımının nasıl gerçekleştirileceğine yönelik öğretmenlere verilen örnekler yer almamaktadır. Sadece bazı kazanımlarda, kazanımın nasıl gerçekleştirileceğine yönelik kazanımın hemen altında açıklamalara yer verilmiştir. Bir başka deyişle, 2012 YYB programında, 2018 YYB programına göre öğretmenlere yol gösterici olması açısından daha fazla bilginin yer aldığı söylenebilir.

Özonat ve Sis (2016) 5. sınıf öğrencileriyle yaptıkları çalışmada, yazma becerisine yönelik uygulamaya konulan YYB dersinin öğrencilerin büyük çoğunluğu tarafından sevilen bir ders olduğunu belirlemiştir. Ayrıca Özonat ve Sis (2016) yaptıkları çalışmada, öğrencilerin büyük çoğunluğunun YYB dersinin yazma becerilerine katkı sağlayacağı inancına sahip olduğu sonucuna ulaşmıştır. Bu durum da YYB dersine yönelik geliştirilen programların önemini daha da artırmaktadır. Geliştirilen programların öğrencilere yazma becerisini kazandırmadaki etkinliği ise ancak programların değerlendirilmesiyle tespit edilebilir. Bir programın etkililiğine yönelik en değerli görüşler ise programın uygulayıcıları olan öğretmenlerden elde edilebilir. İşte bu araştırmada da 2018 YYB programının öğretmen görüşleri doğrultusunda değerlendirilmesi amaçlanmıştır. Alan yazında YYB dersine yönelik Becel (2013), Çarkıt ve Karadüz (2015) ve Özonat ve Sis (2016) tarafından yapılan çalışmalar bulunmakla birlikte mevcut 2018 YYB programına yönelik herhangi bir çalışma yer almamaktadır. Dolayısıyla da bu çalışmanın alan yazına bir katkı sağlayacağı beklenmektedir. Ayrıca yapılan bu araştırmada, öğretmenlerden elde edilen görüşler doğrultusunda 2018 YYB programına yönelik belirlenen eksikliklerin, programın daha sonraki yıllarda yapılacak güncelleme çalışmaları için değerli bir veri kaynağı olacağı düşünülmektedir.

\section{Araştırmanın Modeli}

\section{Yöntem}

Bu araştırmada, mevcut 2018 YYB dersi öğretim programına yönelik öğretmen görüşlerinin belirlenmesi amaçlandığından araştırma modeli, nitel araştırma modellerinden biri olan durum çalışması olarak tasarlanmıştır. Nitel araştırmalar, gözlem, görüşme ve dokuman analizi gibi veri toplama tekniklerinin kullanılarak gerçekleştirildiği araştırmalardır. Nitel araştırmalar, araştırılacak konu veya olayın kendi ortam ve koşullarında gerçekçi ve bütüncül bir yapıda incelenmesine imkan veren araştırmalardır. Durum çalışmaları ise araştırma başlangııında belirlenen araştırma sorularını elde edilen veriler aracılığı ile yanıtlamaya çalışan bir araştırma modelidir (Yıldııım ve Şimşek, 2013). Durum çalışmaları, gözlem, görüşme veya dokümanlar aracılığı ile ulaşılan verilerin derinlemesine incelenmesine imkan sağlayan bir modeldir (Glesne, 2012). Durum çalışmalarında, durumlar bireysel ya da belli bir gruba yönelik olabilir. Ayrıca durum çalışmalarında, araştırılan konu derinlemesine incelendiğinden dolayı az sayıda katılımcıyla gerçekleştirilir (Kaleli Yılmaz, 2015).

\section{Çalışma Grubu}

Araştırmanın çalışma grubunu, Türkiye'nin 4 farklı ilinde görev yapan 15 Türkçe öğretmeni oluşturmaktadır. Görüşleri alınan öğretmenler ise amaçlı örnekleme yöntemlerinden biri olan maksimum çeşitlilik örnekleme yöntemi kullanılarak belirlenmiştir. Maksimum çeşitlilik örnekleme yönteminde amaç, küçük örneklemler belirlemek ve bu örneklemler içerisinde yer alan bireyler arasında çeşitlilik sağlamaktır (Yıldırım ve Şimşek, 2013). Bu araştırmada da çalışma grubunda yer alan bireyler arasındaki çeşitlilik ise öğretmenlerin görev yaptıkları okullar temel alınarak sağlanmıştır. Bu 
kapsamda, okullar belirlenirken, okulların sosyoekonomik düzeyleri arasında çeşitlilik sağlamak için hem il merkezinden hem de köylerden okullar araştırma kapsamına alınmıştır. Ayrıca araştırmanın çalışma grubunda yer alan öğretmenler belirlenirken, en az bir yıl bu dersi vermiş olma şartı aranmıştır. Araştırma kapsamında, görüşleri alınan öğretmenlerin cinsiyet, mesleki kıdem ve YYB dersini verdiği yıl sayısına ilişkin demografik bilgileri Tablo 2'de verilmiştir:

Tablo 2.

Öğretmenlerin Demografik Özellikleri

\begin{tabular}{cccccccc}
\hline & Cinsiyet & \multicolumn{3}{c}{ Mesleki Kıdem } & \multicolumn{2}{c}{ Dersi verdiği yıl sayısı } \\
\hline \multirow{2}{*}{ Erkek } & Kadın & $0-10$ yıl & $11-20$ yıl & 21 yıl üzeri & 1 yıl & 2 yıl & $\begin{array}{c}3 \text { yıl ve } \\
\text { üzeri }\end{array}$ \\
\hline 7 & 8 & 5 & 6 & 4 & 7 & 4 & 4 \\
\hline
\end{tabular}

\section{Veri Toplama Aracı}

Araştırmada, öğretmenlerin 2018 YYB dersi öğretim programına yönelik görüşlerini belirlemek amacıyla yarı yapılandırılmış bir görüşme formu taslağı hazırlanmıştır. Oluşturulan taslak forma ilişkin 5 uzmanın görüşüne başvurulmuş ve uzman görüşleri doğrultusunda taslak formda gerekli düzenlemeler yapılmıştır. Ayrıca taslak görüşme formunda yer alan sorulara ilişkin 3 Türkçe öğretmeniyle de ön deneme gerçekleştirilmiştir. Ön deneme sonucunda, öğretmenler taslakta yer alan soruların anlaşılır olduğunu belirtmiştir. Ön deneme uygulamasından sonra oluşturulan nihai görüşme formunda ise 12 soru yer almaktadır.

\section{Verilerin Toplanması}

Araştırma kapsamında yapılan görüşmeler yüz yüze ve ses kayıt cihazı kullanılarak gerçekleştirilmiştir. Bu kapsamda öncelikle öğretmenlerin müsait olduğu gün ve saat için önceden randevu alınmış ve görüşme esnasında da ses kayıt cihazını kullanmak için izin alınmıştır.

\section{Verilerin Analizi}

Araştırma kapsamında elde edilen verilerin analizinde içerik analizi yönteminden yararlanılmıştır. İçerik analizi yönteminde, araştırma kapsamında elde edilen verilerin açıklanmasını sağlayacak kavram ve ilişkilerin belirlenmesi amaçlanır. Bu amaç doğrultusunda da öncelikle elde edilen verilerin kavramlar haline dönüştürülmesi ve daha sonra da bu kavramların belli bir mantık çerçevesinde organize edilmesi ve böylece elde edilen verileri açıklayan temaların oluşturulması gerekmektedir (Yıldırım ve Şimşek, 2013). Araştırmada, bu analiz yöntemini kullanabilmek için öncelikle ses kayıt cihazına kaydedilen görüşmeler transkript edilmiş ve yazılı hale getirilmiştir. Yazılı hale dönüştürülen görüşme verilerine yönelik kod ve temaların belirlenmesinde ise Maxqda programından yararlanılmıştır. Bu doğrultuda, öncelikle görüşme verilerinden kodlar oluşturulmuş ve elde edilen kodlar da benzerliklerine göre gruplanarak temalar oluşturulmuştur. Daha sonra her bir koda yönelik sıklık değerleri hesaplanmıştır. Ayrıca öğretmenlerin görüşlerini daha iyi yansıtabilmek amacıyla doğrudan alıntılara da yer verilmiştir.

Araştırma kapsamında belirlenen kod ve temaların güvenirliğini sağlamak amacıyla ise görüşme verileri bir başka araştırmacı tarafından daha analiz edilmiş ve diğer araştırmacının elde ettiği kod ve temalar karşılaştırılarak her iki araştırmacı arasındaki uyum yüzdesi hesaplanmıştır. Bu yüzde ise Miles ve Huberman (1994) tarafından önerilen (Görüş birliği sayısı / Görüş birliği + Görüş ayrılığı sayısı) formül aracılığı ile belirlenmiştir. Bu doğrultuda, uyum yüzdesi .93 olarak hesaplanmıştır. Yıldırım ve Şimşek'e (2013) göre bu uyum yüzdesi, araştırma kapsamında elde edilen kod ve temalar için güvenirliğin sağlandığını göstermektedir. 


\section{Bulgular}

YYB dersi öğretim programına yönelik öğretmen görüşlerinden elde edilen bulgular aşağıda alt başlıklar halinde verilmiştir.

\section{YYB Dersi Öğretim Programı'na Yönelik Hizmet İçi Eğitim Alma Durumu}

Öğretmenlerin YYB dersi öğretim programına yönelik hizmet içi eğitim alma durumlarına ilişkin görüşleri ve bu görüşlere ait sıklık dağıımı Tablo 3'te verilmiştir.

Tablo 3.

Öğretmenlerin programa yönelik hizmet içi eğitim alma durumlarına ilişkin görüşlerinin sıklık dağıımı

\begin{tabular}{|c|c|c|c|}
\hline Tema & Alt Tema & Kodlar & $\mathrm{s}$ \\
\hline \multirow{3}{*}{ Hizmet İçi Eğitim } & & Hizmet içi eğitim gerekli & 12 \\
\hline & $\begin{array}{l}\text { HIzmet IÇı Egıtım } \\
\text { Almayanlar }\end{array}$ & $\begin{array}{l}\text { Hizmet içi eğitimin yararı kaliteli olmasına } \\
\text { bağlı }\end{array}$ & 2 \\
\hline & $\begin{array}{l}\text { Hizmet İçi Eğitim } \\
\text { Alanlar }\end{array}$ & Hizmet içi eğitim yararlı & 1 \\
\hline
\end{tabular}

Tablo 3 incelendiğinde, öğretmenlerden sadece biri YYB dersine ilişkin hizmet içi eğitim aldığını belirtmiş ve oldukça da yararlı bulduğunu ifade etmiştir. Hizmet içi eğitim almayan öğretmenlerden ikisi verilen eğitimin kaliteli olması durumunda yararlı olacağını ifade ederken, on iki öğretmen ise mutlaka bu derse ilişkin bir hizmet içi eğitimin verilmesi gerektiğini belirtmiştir. Öğretmenlerin bu duruma ilişkin görüşlerinden bazıları aşağıda verilmiştir:

"Yerinde bir karardı almam. Çünkü YYB dersi öyle kolay bir ders değil." (Öğretmen-13).

"Eğitimin nasıl verileceği önemli. Kalabalık gruplara tek bir hoca anlatacaksa mantıklı değil. Küçük gruplarla bilgi alışverişinin yapılabileceği ortamlarda yararlı olacağını düşünüyorum." (Ö-12)

"Alınması ihtiyaç bu tür derslerde ne yapacağımıza dair bir bilgi birikimine sahip değiliz. Ne yapacağımıza ilişkin bilgi toplamaya kalkıştığımızda bu konu ile ilgili bir yer yok. Kesinlikle ihtiyaç." (Ö5)

Öğretmenlerin yukarıdaki görüşleri incelendiğinde, hizmet içi eğitim alan öğretmenin YYB dersinin zor bir ders olmasından dolayı böyle bir eğitimin gerekli olduğunu düşündüğü; hizmet içi eğitim almayan öğretmenlerin ise yeterli donanıma sahip olmadıkları için böyle bir eğitimin gerekli olduğunu düşündükleri fakat aynı zamanda yapılacak eğitimin kalitesinin de onlara katkı sağlayacak nitelikte olması gerektiğini savundukları görülmektedir.

\section{YYB Dersi Öğretim Programı́na Yer Alan Yeterlilik Alanları}

Öğretmenlerin YYB dersi öğretim programında yer alan yeterlilik alanlarına ilişkin görüşleri ve bu görüşlere ait sıklık dağılımı Tablo 4'te verilmiştir.

Tablo 4.

Öğretmenlerin programda yer alan yeterlilik alanlarına ilişkin görüşlerinin sıklık dağılımı

\begin{tabular}{|c|c|c|}
\hline Tema & Kodlar & $\mathrm{s}$ \\
\hline \multirow{6}{*}{ Yeterlilik alanları } & Yeterlilik alanlarının sıralaması uygun & 10 \\
\hline & Hazırlık bölümüne yönelik süre arttırılabilir & 4 \\
\hline & Öğrencilerin seviyesine uygun değil & 3 \\
\hline & Yaratıcılık ihmal edilmiş & 2 \\
\hline & Sıralama yanlış & 1 \\
\hline & Kararsızım & 1 \\
\hline
\end{tabular}


Tablo 4 incelendiğinde, öğretmenlerden onu öğretim programında YYB için belirlenmiş yeterlilik alanlarının sıralamasını uygun bulurken; bir öğretmen sıralamayı uygun bulmadığını ifade etmiştir. Üç öğretmen ise yeterlilik alanlarının öğrencilerin seviyesine uygun olmadığını, dört öğretmen de hazırlık bölümünün süresinin daha uzun olması gerektiğini belirtmiştir. Görüş belirten öğretmenlerden ikisi de yeterlilik alanları içinde yaratıcılığın ihmal edildiğini ifade etmiştir. Öğretmenlerden biri ise bu konuda kararsız olduğunu belirtmiştir. Öğretmenlerin bu duruma ilişkin görüşlerinden bazıları aşağıda verilmiştir:

"Dersimizin adını yaratıcı yazarlık olduğunu göz önüne alırsak bir taslak oluşturmadan sunuma kadar böyle bir süreç izlenmesinin yerinde olacağını düşünüyorum." (Ö-8)

"Bu bölümlemeleri uygun buldum ama her yazı için bu planlamayı yapmak doğru mu onu bilemiyorum. Ben bu aşamaları her bir yazı etkinliğinde kullandım. En fazla üç hafta sürdü yazılarımızı oluşturmak her seferinde. Programdaki bu planlama çocuğu kopartıyor, yazıdan, süreçten uzaklaştırıyor bence." (Ö-9)

"Ama biraz daha yaratıı kısmında ne yapılabileceği verilmiş olmalı. Hazırlık kısmı geniş olmalı. Yani ben burada yaratıcı kısma önemi, vurguyu göremedim. Klasik bir dersin sunumundaki aşama gibi geldi bana. Beklenenin dışında bir taslak değil. Bizim de üzerine ne yapılabilir diye kafa yormamız gerekir." (Ö-6)

Öğretmenlerin yukarıdaki görüşleri incelendiğinde, YYB dersi öğretim programında yer alan yeterlilik alanlarına yönelik hazırlık, planlama, geliştirme, düzeltme ve sunum olarak yapılan sıralamanın uygun olduğunu düşünen öğretmenler olmasına karşın bu sıralamanın çocukları yazma etkinliklerinden uzaklaştırdığını düşünen öğretmenler olduğu da görülmektedir. Ayrıca yeterlilik alanlarında yaratıcılığa gereken vurgunun yapılmadığını ve bu durumun da yeterlilik alanlarını sıradanlaştırdığını düşünen öğretmenlerin de olduğu görülmektedir.

\section{YYB Dersi Öğretim Programı́nda Yer Alan Kazanımlar}

Öğretmenlerin YYB dersi öğretim programında yer alan kazanımlara ilişkin görüşleri ve bu görüşlere ait sıklık dağılımı Tablo 5'te verilmiştir.

Tablo 5.

Öğretmenlerin programda yer alan kazanımlara ilişkin görüşlerinin sıklık dağı̆ımı

\begin{tabular}{ccc}
\hline Tema & Kodlar & s \\
\hline & Günlük yaşamla ilişkili & 6 \\
\cline { 2 - 3 } Kazanım & Öğrenci seviyesine uygun değil & 5 \\
\cline { 2 - 3 } & Kazanımlar sınıf düzeyine göre farklılaştırılmalı & 3 \\
\cline { 2 - 3 } & LGS sistemine uygun değil & 3 \\
\cline { 2 - 3 } & Öğgrenci seviyesine uygun & 2 \\
\cline { 2 - 3 } & Metin türleri ile ilgili kazanımlar detaylandırılmalı & 2 \\
\cline { 2 - 3 } & Kalabalık sınıflara uygun değil & 1 \\
\hline
\end{tabular}

Tablo 5 incelendiğinde, öğretmenlerin altısı kazanımları günlük yaşamla ilişkili bulduklarını ifade etmişlerdir. Öğretmenlerin beşi ise kazanımların öğrenci seviyesine uygun olmadığını, üçü yaratıcılık kısmını ön plana çıkarmadığını, üçü de kazanımların her sınıf seviyesinde aynı olduğunu belirterek kazanımların sınıf seviyelerine göre farkılış̧ması gerektiğini vurgulamıştır. Öğretmenlerin bu duruma ilişkin görüşlerinden bazıları aşağıda verilmiştir:

"Olumlu aslında. Okuma ve yazma birbirinden ayrı düşünülemez. Yazma da okunan bilgilerin pekiştirilmesini sağlar. Etkili ve doğru yazma. Farkı edebi türleri çocuk tanımalı. Buna fırsat tanıyor." (Ö-7)

"Yaratıcı yazma konusunda da dikkatimi çeken bir kazanım olmadı. Bu kısım eksik gördüm." (Ö-9) 
"Kazanımların tüm sınıf seviyelerinde aynı olmasını uygun bulmuyorum. Ayrıştırılmamış. Kazanımlar konusunda bir sıkıntı var. 5 ve 6. sınıflar biraz daha basitleştirilirken 7 ve 8. sınıflar zorlaştırılabilir bence." (Ö-10)

Öğretmenlerin yukarıdaki görüşleri incelendiğinde, YYB dersi öğretim programında yer alan kazanımlara ilişkin öğrenciler için uygun olduğunu düşünen öğretmenler olmakla birlikte kazanımların 5 ve 6. sınıf düzeylerinde öğrencilerin seviyesinin üzerinde 7 ve 8 . sınıf düzeylerinde ise öğrencilerin seviyesinin altında olduğunu düşünen öğretmenler olduğu da görülmektedir. Ayrıca öğretmenlerin programda yaratıc yazma etkinliklerine imkan veren kazanımlara yer verilmemesini ve de kazanımların her bir sınıf düzeyine göre farklılaştırılmamasını eleştirdikleri görülmektedir.

\section{YYB Dersi Öğretim Programı'nı Uygularken Gerçekleştirilen Öğretme-Öğrenme Süreci}

Öğretmenlerin YYB dersi öğretim programını uygularken gerçekleştirdikleri öğretme-öğrenme sürecine ilişkin görüşleri ve bu görüşlere ait sıklık dağıımı Tablo 6 ' da verilmiştir.

Tablo 6.

Öğretmenlerin programı uygularken gerçekleştirdikleri öğretme-öğrenme sürecine ilişkin görüşlerinin sıklık dağılımı

\begin{tabular}{|c|c|c|}
\hline Tema & Kodlar & $\mathrm{s}$ \\
\hline \multirow{27}{*}{$\begin{array}{c}\text { Öğretme-Öğrenme } \\
\text { Süreci }\end{array}$} & Metnin türünü özeliklerine göre yazma & 5 \\
\hline & Kendini rahatça ifade edebileceği basit etkinlikler & 4 \\
\hline & Görselden hareketle metin oluşturma & 4 \\
\hline & Okuma etkinliği & 4 \\
\hline & Düz anlatım & 4 \\
\hline & Olaya dayalı metinler oluşturma/tamamlama & 3 \\
\hline & Sunum yaptırma & 2 \\
\hline & Anahtar sözcüklerden hareketle metin oluşturma & 2 \\
\hline & Diğer derslerdeki eksiklikleri tamamlama & 2 \\
\hline & Örnek metin üzerinden benzerini oluşturma & 2 \\
\hline & Etkinlik kitaplarından faydalanma & 2 \\
\hline & Soru cevap & 2 \\
\hline & Eleştirel bakış açısını kazandırmaya yönelik etkinlikler & 2 \\
\hline & Serbest yazma & 2 \\
\hline & Kitap oluşturma & 2 \\
\hline & Drama & 1 \\
\hline & Anlama etkinlikleri & 1 \\
\hline & Yazdıkları metinle ilgili görseller çizdirmek & 1 \\
\hline & Ses ve görsellerden hareketle konuşma etkinlikleri & 1 \\
\hline & Farklı metin türlerini iç içe kullanma & 1 \\
\hline & Belgesel izlettirip metin oluşturma & 1 \\
\hline & Birbirlerinin öykü ve görsellerini tamamlama & 1 \\
\hline & Disiplinler arası etkileşime dayalı etkinlikler & 1 \\
\hline & Dikte & 1 \\
\hline & Bakış açısını kavratmaya yönelik etkinlikler & 1 \\
\hline & Dijital kitap oluşturma & 1 \\
\hline & Kavram haritası & 1 \\
\hline
\end{tabular}

Tablo 6 incelendiğinde, görüşme yapılan öğretmenlerden beşi metnin türünün özelliklerini yansıtan metin oluşturma çalışmaları yaptığını ifade ederken, dördü öğrencilerin kendilerini rahat ifade edecekleri basit etkinliklerle başladıklarını, dördü görselden hareketle metin oluşturma çalışmaları yaptıklarını, dördü okuma etkinlikleri gerçekleştirdiklerini ve dördü de düz anlatımı kullandıklarını belirtmişlerdir. Sadece iki öğretmen kitap oluşturduklarını hatta bunlardan biri dijital kitap 
oluşturduğunu vurgulamıştır. Öğretmenlerin bu duruma ilişkin görüşlerinden bazıları aşağıda verilmiştir:

"Geçen yıl biz bir dijital kitap yayımladık. Bu kitabın konusu doğa sevgisiydi. Doğa ile ilgili karikatürlerden yola çıktık. Dünya çapında ödül almış karikatürleri çocuklarla paylaştım. Herkes istediğini seçti oradan yola çıkarak yine tür sınırlaması yapmadan yazılar yazdılar ve bunları yazarken yeterlilik alanları aşamasından geçirdik. Dijital platformda birleştirdik. Internet üzerinden bu yazıları dergi formatına çevirdik. Öğrenciler arasında son dönemde çok popüler ve önemli olan Wattpad'te dijital kitabımızı yayımladık." (Ö-9)

"Metin türlerini kavratmada da kullanabilir miyiz diye düşünüp bir olay seçtik kendimize farklı metin türlerinde anlatmalarını istedik. Aynı olay kısa öykü olsaydı nasıl yazardık, fabl olsaydı nasıl, masal olsaydı nasıl diye çeşitlendirdik. Bu onlara çok keyifli geldi." (Ö-15)

"Şimdi bu yaratıcı yazarlıkta temelde olan bir şeyi yani okumayı es geçemeyiz. Usta hikayeci ve yazar ve şairlerimizin yapıtlarını okumalarını ısrarla tavsiye ediyoruz. Bu donanım oluştuktan sonra yazma gelir." (Ö-8)

Öğretmenlerin yukarıdaki görüşleri incelendiğinde, öğretmenlerin YYB dersi öğretim programını temel alarak farklı etkinlik türlerine derslerinde yer verdikleri ve dijital kitap, bir olayı farklı metin türleriyle ifade etme gibi öğrencilerin ilgisini çekecek etkinliklerin bu ders kapsamında yer alması gerektiğini ifade ettikleri görülmektedir. Ayrıca öğretmenlerin yazma ve okuma becerilerinin birbirlerinin gelişimine katkı sağlayan beceriler olduğunu ve bu nedenle de okuma becerine yönelik etkinliklere de YYB dersi kapsamında yer verilmesi gerektiğini düşündükleri görülmektedir.

\section{YYB Dersi Öğretim Programı́nı Uygularken Kullanılan Ölçme Araçları}

Öğretmenlerin YYB dersi öğretim programını uygularken kullandıkları ölçme araçlarına ilişkin görüşleri ve bu görüşlere ait sıklık dağılımı Tablo 7'de verilmiştir.

Tablo 7.

Öğretmenlerin programı uygularken kullandıkları ölçme araçlarına ilişkin görüşlerinin sıkık dağılımı

\begin{tabular}{|c|c|c|c|}
\hline Tema & Alt Tema & Kodlar & $\mathbf{s}$ \\
\hline \multirow{13}{*}{$\begin{array}{l}\text { Ölçme } \\
\text { Araçları }\end{array}$} & \multirow{7}{*}{ Süreç Odaklı } & Derse katılım & 4 \\
\hline & & Dersteki etkinlikler & 2 \\
\hline & & Akran değerlendirme & 2 \\
\hline & & Defter & 2 \\
\hline & & Portfolyo & 1 \\
\hline & & Okudukları kitapları anlattırma & 1 \\
\hline & & Film izlettirip değerlendirme & 1 \\
\hline & \multirow{6}{*}{ Sonuç Odaklı } & Yazılı sınav & 11 \\
\hline & & Kompozisyon kuralları & 9 \\
\hline & & Çoktan seçmeli sorular & 2 \\
\hline & & Açık uçlu sorular & 2 \\
\hline & & Kısa cevaplı sorular/Boşluk & 1 \\
\hline & & Doğru yanlış soruları & 1 \\
\hline
\end{tabular}

Tablo 7 incelendiğinde, on bir öğretmen YYB dersinin değerlendirme sürecinde yazılı sınavı tercih ettiklerini belirtmiştir. Dokuz öğretmen kompozisyon kurallarına göre değerlendirme yaptığını, dört öğretmen ise derse katılımı ön planda tuttuğunu belirtmiştir. Süreç değerlendirmenin daha az tercih edildiği görülen görüşmelerde iki öğretmenin akran değerlendirmeyi, sadece bir öğretmenin portfolyoyu kullandığı görülmektedir. Öğretmenlerin bu duruma ilişkin görüşlerinden bazıları aşağıda verilmiştir: 
"Sınav yapmak durumundayız evet ama ben açıkçası bunu direkt sınav gibi yapmıyorum. O güne kadar yapılmış çalışmaların bir dosyada toplanması, onun teslim edilmesi, onun devam edilmesi şeklinde yapıyorum." (Ö-9)

"Yazılı sınav yapıyoruz. Kullandığımız yöntem ve tekniklere benzer sorular hazırlıyoruz. Kağıtlara bakarken çocuk kendini iyi ifade etmiş mi, yazım ve noktalama kurallarına uygun mu, ama en önemlisi ifadeye dikkat ediyorum." (Ö-4)

"Kağıdın düzeni, yazım noktalama vs. kompozisyon değerlendirme ölçütlerimi kullanıyorum." (Ö-2)

Öğretmenlerin yukarıdaki görüşleri incelendiğinde, öğrencilerin yazma becerisine yönelik yeterliliğini süreç içerisindeki performanslarına göre değerlendiren öğretmenler olmakla birlikte öğrencilerin yeterliliğini sınavlarla yani sonuç odaklı değerlendiren öğretmenlerin de olduğu görülmektedir.

\section{YYB Dersi Öğretim Programı Uygulanırken Karşılaşılan Sorunlar}

Öğretmenlerin YYB dersi öğretim programını uygularken karşılaştıkları sorunlara ilişkin görüşleri ve bu görüşlere ait sıklık dağılımı Tablo 8'de verilmiştir.

Tablo 8.

Öğretmenlerin programı uygularken karşılaştıkları sorunlara ilişkin görüşlerinin sıklık dağılımı

\begin{tabular}{|c|c|c|}
\hline Tema & Kodlar & $\mathrm{s}$ \\
\hline \multirow{14}{*}{$\begin{array}{l}\text { Uygulamada } \\
\text { Karşılaşılan } \\
\text { Sorunlar }\end{array}$} & Hazırbulunuşluk & 8 \\
\hline & Ders kitabının olmayışı & 6 \\
\hline & Öğretmenlerin yetersizliği & 5 \\
\hline & Sınav sistemi & 5 \\
\hline & Yazma etkinliklerine isteksizlik & 5 \\
\hline & Dersin seçiminin öğrencilere bırakılmaması & 4 \\
\hline & Okuma alışkanlığının olmaması & 4 \\
\hline & Seçmeli derslerin işlenişinde bir standardın olmayışı & 4 \\
\hline & Programın öğretmenlere kılavuzluk edememesi & 2 \\
\hline & Kılavuz kitabının olmayışı & 2 \\
\hline & Seçmeli derslere verilen önemin az olması & 2 \\
\hline & Herhangi bir sorunla karşılaşmadım & 2 \\
\hline & Hayal dünyası darlığı & 1 \\
\hline & Öğrencilerdeki dikkat dağınıklığı & 1 \\
\hline
\end{tabular}

Tablo 8 incelendiğinde, öğretmenlerden sekizi programı uygularken karşılaştıkları sorunlardan birisi olarak öğrencilerin hazırbulunuşluk düzeyinin düşük olmasını göstermektedir. Görüşme yapılan öğretmenlerden altısı ders kitabının olmayışını en büyük eksiklik ve sorun olarak görürken, beşi mevcut sınav sistemini, beşi öğretmenlerin yetersizliğini, beşi ise öğrencilerin yazma etkinliklerine yönelik isteksizliğini sorun olarak görmektedir. Dört öğretmen öğrencilerin okuma alışkanlığının olmayışını, dört öğretmen dersin seçiminin öğrenciye bırakılmayışını, dört öğretmen ise seçmeli derslerin işlenişinde bir Türkçe dersindeki gibi standardın olmayışını uygulamadaki sorunlar olarak belirtmiştir. Öğretmenlerin bu duruma ilişkin görüşlerinden bazıları aşağıda verilmiştir:

"Kitap olmayışı. Bu dersin kitabı olsaydı daha derli toplu yolumuzu çizebilirdik." (Ö-2)

"Özellikle 8. sınıflarda sınava hazırlık olarak görülüyor." (Ö-8)

"Çocuklarda okuma alışkanlığının olmayışı bu dersin öğretimini zorluyor." (Ö-14)

Öğretmenlerin yukarıdaki görüşleri incelendiğinde, öğretmenlerin YYB dersi için kendilerine rehberlik edecek bir kitabın olmayışının ve öğrencilerin okuma becerilerindeki yetersizliklerinin programın uygulama sürecini olumsuz etkilediği görüşünde oldukları görülmektedir. Ayrıca öğretmenlerin özellikle 8. sınıf düzeyinde mevcut sınav sisteminden dolayı bu derse gereken önemin verilmediği ve YYB dersinin öğrencilerin Liselere Giriş Sınavı'na (LGS) çalışacakları bir ders olarak 
görüldüğg̈ ve bu durumun da programın uygulanma sürecini zorlaştırdığı düşüncesinde oldukları söylenebilir.

\section{YYB Dersi İçin Belirlenen Süre}

Öğretmenlerin YYB dersi için belirlenen süreye ilişkin görüşleri ve bu görüşlere ait sıklık dağılımı Tablo 9'da verilmiştir.

Tablo 9.

Öğretmenlerin YYB dersi için belirlenen süreye ilişkin görüşlerinin sıklık dağılımı

\begin{tabular}{ccc}
\hline Tema & Kodlar & $\mathrm{s}$ \\
\hline \multirow{2}{*}{ Süre } & Yeterli & 2 \\
\cline { 2 - 3 } & Yeterli değil & 13 \\
\hline
\end{tabular}

Tablo 9 incelendiğinde, görüşme yapılan öğretmenlerden on üçü YYB dersi için haftada iki saati yetersiz bulurken iki öğretmen ise yeterli bulduğunu ifade etmiş̧ir. Öğretmenlerin bu duruma ilişkin görüşlerinden bazıları aşağıda verilmiştir:

"Yeterli. Daha fazlasına lüzum görmüyorum. Çocuğun özgür alanında bir şeyleri kendi kendine de yapması gerekiyor. Biz bu derste ateşi fitilliyoruz. O ondan sonra kendi başına devamını getiriyor." (Ö9)

"Kesinlikle değil. Yazma iki saat işi değil bence. Daha fazla olmalıydı." (Ö-12)

Öğretmenlerin yukarıdaki görüşleri incelendiğinde, bu dersin yazma becerisi için sadece bir başlangıç olduğu ve öğrencilerin bu derste kazandıkları becerileri ders dışında da kullanmaları ve geliştirmeleri gerektiğini savunan öğretmenlerin ders için ayrılan süreyi yeterli buldukları fakat yazma becerisinin zor ve zaman isteyen bir beceri olduğunu düşünen öğretmenlerin ise ders için ayrılan süreyi yetersiz buldukları görülmektedir.

\section{YYB Dersinin Seçmeli Bir Ders Olması}

Öğretmenlerin YYB dersinin seçmeli bir ders olmasına ilişkin görüşleri ve bu görüşlere ait sıklık dağılımı Tablo 10'da verilmiştir.

Tablo 10.

Öğretmenlerin YYB dersinin seçmeli bir ders olmasına ilişkin görüşlerinin sıklık dağılımı

\begin{tabular}{ccc}
\hline Tema & Kodlar & $\mathrm{s}$ \\
\hline YYB Dersinin Seçmeli & Zorunlu olması gerekir & 1 \\
\cline { 2 - 3 } Olması & Seçmeli olması gerekir & 14 \\
\hline
\end{tabular}

Tablo 10 incelendiğinde, görüşme yapılan öğretmenlerden biri hariç hepsi YYB dersinin Türkçe eğitimine ilişkin seçmeli bir ders olarak verilmesini doğru bir karar olarak görmektedir. Öğretmenlerin bu duruma ilişkin görüşlerinden bazıları aşağıda verilmiştir:

"YYB gerçekten seçmeli ders olarak işlendiğinde gerekli olduğunu düşünüyorum. Çünkü yazma konusunda da okuma becerileri konusunda da yeterli değiliz. Ülke olarak da değiliz. Özellikle yazma konusunda çocuklar çok isteksiz. Ama bu bir ders olarak önlerine geldiğinde biraz daha çaba gösteriyorlar." (Ö-1)

"Seçmeli ders gibi ayrı bir ders değil ama Türkçe dersine ek bir ders şeklinde olsa öğrencinin bakışııın da olumlu anlamda değişeceğini düşünüyorum." (Ö-13)

Öğretmenlerin yukarıdaki görüşleri incelendiğinde, seçmeli olarak verilmesini uygun bulan ve YYB dersinin tam anlamıyla uygulandığında, Türkiye'de ki öğrencileri yazma etkinliklerine motive etmede katkı sağlayacağını düşünen öğretmenler olmasına karşın bu dersin Türkçe dersi gibi zorunlu bir ders olduğunda öğrencilerin YYB dersine daha çok motive olacaklarını düşünen öğretmen olduğu da görülmektedir. 


\section{YYB Dersi Dışında Vermek İstenilen Diğer Seçmeli Dersler}

Öğretmenlerin YYB dersi dışında vermek istedikleri diğer seçmeli derslere ilişkin görüşleri ve bu görüşlere ait sıkık dağıımı Tablo 11'de verilmiştir.

Tablo 11.

Öğretmenlerin YYB dersi dışında vermek istedikleri diğer seçmeli derslere ilişkin görüşlerinin sıklık dağııımı

\begin{tabular}{|c|c|c|c|}
\hline Tema & Alt Tema & Kodlar & $\mathbf{s}$ \\
\hline \multirow{9}{*}{$\begin{array}{l}\text { Diğer } \\
\text { Seçmeli } \\
\text { Dersler }\end{array}$} & \multirow{4}{*}{ Okuma Becerileri } & Türkçe için en temel beceri alanı olması & 2 \\
\hline & & Okuma alışkanlığı kazandırmak & 2 \\
\hline & & Öğretmenlerin okumaya ilgi duyması & 2 \\
\hline & & $\begin{array}{l}\text { Seçmeli dersler içinde okullarda uygulanabilirliği en } \\
\text { kolay olan derstir }\end{array}$ & 1 \\
\hline & $\begin{array}{c}\text { İletişim ve Sunu } \\
\text { Becerileri }\end{array}$ & Öğrencilerin iletişim konusunda yetersiz oluşu & 7 \\
\hline & \multirow{4}{*}{$\begin{array}{c}\begin{array}{c}\text { Yaşayan Diller ve } \\
\text { Lehçeler }\end{array} \\
\end{array}$} & Türk dilinin önemini öğrenciye kazandırmak & 2 \\
\hline & & Öğrencilere farklı bakış açısı kazandırmak & 1 \\
\hline & & YYB dersi yeterli & 1 \\
\hline & & Seçmeli derslerin bir katkısı yok & 1 \\
\hline
\end{tabular}

Tablo 11 incelendiğinde, görüşme yapılan öğretmenlerin Türkçe eğitiminde YYB dersi dışında vermek istedikleri derslerin başında "Okuma Becerileri" ve "iletişim ve Sunu Becerileri" derslerinin geldiği görülmektedir. Görüşme yapılan iki öğretmen, okumanın Türkçe için en temel beceri alanı olduğu için, iki öğretmen, okuma alışkanlığı kazandırmak için, iki öğretmen, öğretmenlerin okumaya ilgi duydukları için ve bir öğretmen ise seçmeli dersler içinde uygulanması en kolay ders olduğu için "Okuma Becerileri" dersini vermek istediğini belirtmiştir. Yedi öğretmen ise öğrencilerin iletişim becerileri açısından yetersiz oldukları için "iletişim ve Sunu Becerileri" dersini vermek istediğini ifade etmiştir. Görüşme yapılan öğretmenlerden ikisi ise Türk dilinin önemini öğrencilere kazandırmak için "Yaşayan Diller ve Lehçeler" dersini vermek istediğini belirtmiştir. Görüşme yapılan öğretmenlerden biri ise seçmeli derslerin hiçbir katkısı olmadığını düşünmekte ve hiçbir seçmeli dersi vermek istemediğini belirtmiştir. Ayrıca yine öğretmenlerden biri ise YYB dersinin yeterli olduğunu ve YYB dersi dışında hiçbir seçmeli ders vermek istemediğini ifade etmiştir. Öğretmenlerin bu duruma ilişkin görüşlerinden bazıları aşağıda verilmiştir:

"iletişim ve sunu becerilerine girmek isterdim. Çünkü öğrencilerin kendilerini ifade etmeleri konusunda ciddi sıkıntıları var. Yıl boyu birlikte oturduğu arkadaşının, arkadaşlarının arasında kalkıp iki cümle kuramıyor. Cümleler karışıyor. Heyecan başlıyor. Toplum içinde kendini rahatça ifade edebilmeyi öğrenmeli çocuk." (Ö-5)

"Okuma becerilerini vermek isterdim. Okumanın kıymetini bildiğimi düşünüyorum. Bunu çocuklara aktarabilmeyi, onlara kitap okuma alışanlığını kazandırabilmeyi, bunu ömürlerine yaymalarını, çocuklarına öğretebilmelerini sağlamayı çok isterdim." (Ö-2)

"Yaşayan Diller ve Lehçeler dersini vermek isterdim. Öğrencilerin bakış açııını biraz değiştirirdi. Tek dil biraz kısır. iki dil üç dil. Öğrencilerin bakış açııını değiştirmek adına faydalı olurdu." (Ö-8)

Öğretmenlerin yukarıdaki görüşleri incelendiğinde, öğretmenlerin, öğrencilerin yazma becerisi dışında okuma ve iletişim becerilerinde ve de ikinci bir dil öğreniminde de eksiklikleri olduğunu ve öğrencilerin bu eksikliklerinin de diğer seçmeli dersler aracılığıyla giderileceğini düşündükleri görülmektedir. 
Türkçe Eğitimine Yönelik Seçmeli Ders Önerileri

Öğretmenlerin Türkçe eğitimine yönelik seçmeli ders önerileri ve bu derslere ait sıklık dağııımı Tablo 12 ' de verilmiştir.

Tablo 12.

Öğretmenlerin Türkçe eğitimine yönelik önerdikleri seçmeli derslerin sıklık dağılımı

\begin{tabular}{ccc}
\hline Tema & Kodlar & $\mathrm{s}$ \\
\hline & Diksiyon & 5 \\
\cline { 2 - 3 } Türkçe Eğitimine İlişkin & Drama & 3 \\
\cline { 2 - 3 } $\begin{array}{c}\text { Önerilen Seçmeli } \\
\text { Dersler }\end{array}$ & Konuşma teknikleri & 2 \\
\cline { 2 - 3 } & Görgü kuralları & 2 \\
\cline { 2 - 3 } & Öneri yok & 2 \\
\cline { 2 - 3 } & Dilbilgisi & 1 \\
\cline { 2 - 3 } & Hılı okuma teknikleri & 1 \\
\hline
\end{tabular}

Tablo 12 incelendiğinde, görüşme yapılan öğretmenlerin beşi YYB dersi dışında Türkçe eğitimine ilişkin seçmeli ders önerisi olarak diksiyon dersini vermiştir. Üç öğretmen drama dersini, iki öğretmen konuşma teknikleri ve iki öğretmen ise görgü kuralları dersini önermiştir. Öğretmenlerin bu duruma ilişkin görüşlerinden bazıları aşağıda verilmiştir:

"Bu soruyu sormanız beni çok mutlu etti. Bu çok ciddi bir eksiklik. Tüm okullarda verilmesi gereken bir ders. Diksiyon. Küçük sınıflarda başlanmalı. Türkçe aslında bilindiğinin aksine yazıldığı gibi konuşulan bir dil değil. illkokul düzeyinde bu ders verilmeli ki erken yaşlarda çözülmeli." (Ö-5)

"Halk Kültürü, görgü kuralları diye bir ders vardı. Böyle kozmopolit şehirlerde bu tür bölge okullarında çok gerekli bir ders olduğunu düşünüyorum. Davranış sorunları bizim çok zamanımızı alıyor. Bu temel görgü kurallarını evden öğrenmedikleri için biz tamamlamak zorunda kalıyoruz." (Ö-7)

Öğretmenlerin yukarıdaki görüşleri incelendiğinde, öğretmenlerin Türkçe eğitimine yönelik olarak öğrencilere katkı sağlayacağını düşündükleri farklı ders önerileri olduğu görülmektedir. Bu doğrultuda öğretmenlerin, öğrencilerin diksiyon, görgü kuralları gibi alanlarda beceri kazanmasını destekleyecek farklı derslerin seçmeli ders havuzuna dahil edilmesinden yana oldukları söylenebilir.

\section{YYB Dersi Öğretim Programı'nın Güçlü ve Zayıf Yönleri}

Öğretmenlerin YYB dersi öğretim programının güçlü ve zayıf yönlerine ilişkin görüşleri ve bu görüşlere ait sıklık dağıımı Tablo 13'te verilmiştir.

Tablo 13.

Öğretmenlerin programın güçlü ve zayıf yönlerine ilişkin görüşlerinin sıklık dağılımı

\begin{tabular}{|c|c|c|c|}
\hline Tema & Alt Tema & Kodlar & $\mathrm{s}$ \\
\hline \multirow{10}{*}{$\begin{array}{l}\text { Güçlü ve } \\
\text { Zayıf Yönler }\end{array}$} & \multirow{6}{*}{$\begin{array}{l}\text { Güçlü } \\
\text { Yönler }\end{array}$} & $\begin{array}{c}\text { Yazma alanına yönelik yeteneği olan öğrencilerin tespit } \\
\text { edilebilmesi }\end{array}$ & 6 \\
\hline & & Günlük yaşamda bu beceriyi kullanabilmeleri & 4 \\
\hline & & Yazma becerilerini geliştirme & 2 \\
\hline & & Hayal dünyasını geliştirme & 1 \\
\hline & & Öğrencileri yazma becerisine yönelik motive etmesi & 1 \\
\hline & & Öğrenciler hakkında bilgi sahibi olma & 1 \\
\hline & \multirow{4}{*}{ Zayıf Yönler } & $\begin{array}{c}\text { Programın öğretmenlere yeteri kadar kılavuzluk } \\
\text { edememesi }\end{array}$ & 7 \\
\hline & & Öğrencilerin yazma becerisine yönelik ilgilerinin olmaması & 5 \\
\hline & & $\begin{array}{l}\text { Seçmeli derslerin zorunlu derslere göre önemsiz } \\
\text { algılanması }\end{array}$ & 5 \\
\hline & & Öğretmenlerin bu dersi verecek yetkinlikte yetiştirilmemesi & 4 \\
\hline
\end{tabular}




\begin{tabular}{ccc}
\hline & Öğrencilerin okuma alışkanlığının olmayışı & 3 \\
\cline { 2 - 3 } & Program öğrenci seviyesine uygun değil & 3 \\
\cline { 2 - 3 } & Kaynak/ materyal/ etkinlik örneği eksikliği & 2 \\
\cline { 2 - 3 } & Dersin kapsamının sınırlı olması & 2 \\
\cline { 2 - 3 } & Derselilerin öğrenci isteğine bırakılmaması & 2 \\
\hline
\end{tabular}

Tablo 13 incelendiğinde, görüşme yapılan öğretmenlerin altısı YYB programının güçlü yönleri olarak yazma alanında yeteneği olan öğrencilerin keşfedilmesi konusunda imkan sağlamasını, dördü ise öğrencilerin günlük yaşamda bu becerinin kullanılabilmesini göstermektedir. YYB programının zayıf yönleri olarak ise yedi öğretmen programın kendilerine yeteri kadar kılavuzluk edemeyişini, beş öğretmen öğrencilerin yazma becerisine ilgisinin olmayışını, beş öğretmen seçmeli derslerin zorunlu derslere göre daha önemsiz algılanışını belirtmiştir. Görüşme yapılan öğretmenlerin dördü ise öğretmenlerin bu dersi verebilecek yetkinlikte yetiştirilmemiş olduğunu vurgulamıştır. Öğretmenlerin bu duruma ilişkin görüşlerinden bazıları aşağıda verilmiştir:

"Yazmaya hevesli öğrencilerin, yazarlığa ilk adımlarını oluşturması. Yetenekli öğrencilerin kendini ortaya çıkarmasını sağlıyor." (Ö-8)

"Hayatta karşılarına çıkabilecek bir beceriyi kazandırması güzel." (Ö-2)

"Bize bir kılavuz yok. Bizim yapabileceğimiz etkinlik örnekleri yok. Biz internetten bulabildiğimiz etkinliklerle bir şeyler yapıyoruz. Eba bu konuda yetersiz. Etkinlik anlamında zayıf." (Ö-4)

"Öğretmenlerin sanırım bu konuda tam yetkinleşmemiş olması. Türkçe öğretmenlerinin yazma becerilerinin altında yatan alt birimleri bilmiyor oluşları. Yazma tamam ama yazma becerileri ve yaratıcı yazarlık kısmı ben de sempozyum ve seminerlere katılmamış olsaydım ne yapacağımı bilmezdim. Hala da tam olduğumu düşünmüyorum. Öğretmen meslek eğitimindeki bu konudaki eksiklikler giderilmeli." (Ö-15)

"Öğrenci ve veli seçmeli derslere farklı bakıyor. Buradan alacağı notun düşük olmasına tahammül edemiyor. Siz eğer bu dersi layıkıyla işlerseniz vereceğiniz notlar bunlar değil aslında. Seçmeli derste yüksek not vermezseniz sorun yaşarsınız. Veli çocuğunun bir yarışta olduğunu düşünüyor. Bu yarışta da seçmeli ders gibi bir dersle sırtında bir ağırlıkla koşmasını istemiyor. Onun için yüksek ve biraz da şişirilmiş notlarla devam ediyorsunuz." (Ö-3)

Öğretmenlerin yukarıdaki görüşleri incelendiğinde, öğretmenler, geleceğin ünlü yazarlarının ortaya çıkmasına imkan vermesini YYB dersi öğretim programının güçlü yönü olarak görmektedir. Ayrıca öğrencilerin derste öğrendikleri bilgileri günlük yaşamlarında kullanabilmelerini de programın bir diğer güçlü yönü olarak görmektedir. Öğretmenler, YYB dersi öğretim programının zayıf yönleri olarak ise öğretme-öğrenme sürecinde öğretmenlere kılavuzluk edecek etkinlik örneklerinin olmamasını ve velilerin YYB dersine gereken önemi vermediklerinden dolayı öğretmenlerin objektif değerlendirme yapamamalarını göstermektedir. Ayrıca öğretmenler, YYB dersi için kendilerini mesleki açıdan yetersiz bulmakta ve bunu da yine programın zayıf yönü olarak görmektedir.

\section{YYB Dersi Öğretim Programı́na Yönelik Öneriler}

Öğretmenlerin YYB dersi öğretim programına yönelik önerileri ve bu önerilere ait sıklık dağılımı Tablo 14'te verilmiştir.

Tablo 14.

Öğretmenlerin programa yönelik önerilerinin sıklık dağıımı

\begin{tabular}{ccc}
\hline Tema & Kodlar & $\mathrm{s}$ \\
\hline \multirow{2}{*}{ Öneriler } & Derse yönelik bir etkinlik kitabı oluşturulmalı & 8 \\
\cline { 2 - 3 } & Hizmet içi eğitim verilmeli & 6 \\
\hline
\end{tabular}




\begin{tabular}{cc}
\hline Öğrenciyi derse girecek öğretmen belirlemeli & 3 \\
\cline { 2 - 2 } Dersle ilgili materyallerin okullara sağlanması & 3 \\
\hline Dersin seçimini öğrenciler yapabilmeli & 3 \\
\hline Oersi alacak öğrenciler için belli bir kontenjan belirlenmeli & 2 \\
\hline 2018 YYB dersi öğretim programındaki eksiklikler giderilmeli & 2 \\
\hline Seçmeli dersler öğretmenlerin tercihine bırakılmalı & 2 \\
\hline Öğrenci dersi seçmeden önce ders hakkında bilgilendirilmeli & 2 \\
\hline SYB dersi Okuma Becerileri ve İletişim ve Sunu Becerileri derslerinden & 2 \\
\hline sençmeli derslere yönelik MEB'e bilgi verilmeli & 1 \\
\hline İdareciler seçmeli dersler hakkında bilgi sahibi olmalı & 1 \\
\hline Ders Türkçe dersi kapsamına alınmalı & 1 \\
\hline Ders kapsamında yazarlar davet edilebilmeli & 1 \\
\hline EBA'da derse katkı getirecek etkinlikler olmalı & 1 \\
\hline
\end{tabular}

Tablo 14 incelendiğinde, görüşme yapılan öğretmenlerin sekizi YYB programına yönelik bir etkinlik kitabının oluşturulmasını önerirken, altısı mutlaka bu ders ile ilgili bir hizmet içi eğitim verilmesi gerektiğini önermiştir. Öğretmenlerin üçü öneri olarak dersin seçiminin öğrenciler tarafından yapılabilmesini, üçü ise bu dersle ilgili materyallerin okullara sağlanmasını belirtmiştir. ìki öğretmen de öğretmen adaylarına üniversitelerde YYB dersine ilişkin eğitim verilmesi gerektiği konusunda görüş bildirmiştir. Öğretmenlerin bu duruma ilişkin görüşlerinden bazıları aşağıda verilmiştir:

"Öğretim programı dışında taslak etkinlik programları oluşturulsun. Bizim sınıfa uyarlayabileceğimiz, derleyebileceğimiz." (Ö-4)

"Bakanlığın bu konuda kaliteli bir hizmet içi eğitim vermesi gerekiyor. Alanında uzman hocalardan, üniversitelerle iş birliği yaparak." (Ö-15)

"Okulun mekan şartları uygun olması lazım. Kütüphanesinin ve bilgisayar donanımlarının tam olması Iazım. Okulların hayal dünyasını geliştirecek sınıflarının olması lazım." (Ö-13)

Öğretmenlerin yukarıdaki önerileri incelendiğinde, YYB dersi öğretim programının daha etkili uygulanabilmesi için öğretme-öğrenme sürecinde kendilerine yol gösterecek etkinlik örneklerinin yer aldığı ders materyallerinin geliştirilmesini, yazma becerisine yönelik olarak mesleki gelişimlerine katkı sağlayacak nitelikli hizmet içi eğitimlerin düzenlenmesini ve okulların, öğrencilerin yazma etkinliklerine daha kolay motive olmalarını ve yazma becerisini daha kolay kazanmalarını sağlayacak şekilde donanımlı hale getirilmesini önerdikleri görülmektedir.

\section{Tartışma, Sonuç ve Öneriler}

Araştırma kapsamında incelenen 2018 YYB dersi öğretim programına yönelik dikkat çeken en önemli noktalardan birisi programda yaratıcılığa gereken önemin verilmemesidir. Öğretmenlerle yapılan görüşmelerde de öğretmenlerin bir kısmı bu durumu özellikle vurgulamıştır. 2018 YYB dersi öğretim programında yer alan kazanımlar incelendiğinde de öğrencilerin yaratıcı yazma becerisine yönelik kazanımlara programda yer verilmediği görülmektedir. Ayrıca yine 2018 programında "öğretim programının uygulanması sürecinde dikkat edilecek hususlar" bölümünde de yaratıcı yazmaya yönelik hiçbir açıklama yer almamaktadır. Oysaki yazma becerisi, içinde yaratıcılığı barındıran bir süreçtir (Maltepe, 2006; Ungan, 2007). Dolayısıyla da YYB dersini sadece yazma becerisini geliştiren bir ders olarak değil; yaratıcı yazma becerilerini geliştiren bir ders olarak da görmek gerekmektedir. YYB dersinin öğrenciler tarafından sevilen bir ders olması ve dersin istenilen gerçek amacına ulaşması da bu duruma bağlıdır. Alanyazında yapılan çalışmalar da bu görüşü desteklemektedir. Kasap (2019) tarafından 4. sınıf öğrencileriyle yapılan çalışmada, öğrencilerin yaratıcı yazmaya yönelik yapılan etkinliklerde eğlendikleri ve yazılı anlatıma yönelik tutumlarının olumlu yönde değiştiği belirlenmiştir. Yine Susar Kırmızı ve Beydemir (2012) ve Özdemir ve Çevik (2018) tarafından 5. sınıf öğrencileriyle yapılan çalışmalarda da yaratıcı yazma etkinliklerinin öğrencilerin yazmaya yönelik bakış açılarını 
olumlu yönde etkilediği belirlenmiştir. Öğrencilerin yaratıcı yazmaya yönelik etkinliklerde mutlu olmalarının nedeni ise onlara tanınan serbestliktir. Bir başka deyişle, öğrencilerin yazma etkinliğini gerçekleştirirken kendi ilgi alanlarını ve kendi hayal güçlerini kullanmalarına izin verilmesi onların yazma etkinliğinden zevk almalarını sağlayacaktır. Aksi durumda ise yazma etkinliği, öğrenciler için sıkıcı bir hale dönüşebilir. Yılmaz'a (2019) göre de yazma etkinlikleri, öğrencilerin ilgi alanlarına uygun olmadığında, bu durum öğrencilerin etkinliklerden sıkılmasına neden olmaktadır. Karakoç Öztürk (2012) tarafından yapılan çalışmada da yazma etkinliği sırasında kendilerine serbestlik tanınan öğrencilerin kendilerine serbestlik tanınmayan öğrencilere göre yazma becerisine yönelik kaygılarııın daha düşük olduğu belirlenmiştir.

Öğretmenlerle yapılan görüşmelerde, elde edilen önemli bulgulardan birisi de öğretmenlerin bu derse yönelik öğretme-öğrenme sürecinde teknolojiden çok fazla yararlanmadıklarıdır. Görüşme yapılan öğretmenlerden sadece birisi bu ders kapsamında öğrencilerine dijital kitap hazırlattığını belirtmiştir. Oysaki içinde yaşadığımız dijital çağda bu ders kapsamında teknolojiden daha fazla yararlanılması beklenmektedir. 2012 YYB dersi öğretim programında da bu gerçekten yola çıkılarak teknolojiye özel bir vurgu yapılmıştır. Bu kapsamda, 2012 programında "Teknoloji Çağında Yazma Eylemi" başlığı altında bir bölüm de yer almaktadır. 2012 YYB dersi öğretim programını inceleyen Becel (2013) de bu duruma dikkat çekmiş ve programın en önemli özelliğinin teknolojik gelişmeleri esas alması olduğunu belirtmiştir. 2012 programında teknolojiye yapılan bu vurguya rağmen Çarkıt ve Karadüz (2015) yaptıkları çalışmada, bu çalışmadan elde edilen bulgulara benzer olarak öğretmenlerin çoğunun YYB dersi kapsamında teknolojiden yararlanmadıklarını belirlemiştir. 2018 YYB dersi öğretim programı teknoloji bağlamında incelendiğinde ise 2012 programında olduğu kadar teknolojiye vurgu yapılmadığı da görülmektedir. Çarkıt ve Karadüz'e (2015) göre, öğrencilerin derse motive olmaları ve derslerin öğrenciler açısından etkili olabilmesi için öğretim teknolojilerinden derslerde olabildiğince yararlanılmalıdır. Ayrıca 2018 yılında geliştirilen tüm öğretim programlarında (matematik, fen bilimleri, müzik, sosyal bilgiler vb.) Türkiye Yeterlilikler Çerçevesinde sekiz anahtar yetkinlik belirlenmiştir. Bu yetkinliklerden dördüncüsü ise Dijital Yetkinlik'tir. Bu doğrultuda, aslında sadece YYB dersi için değil; tüm derslerde öğretmenlerden beklenilen dijital yetkinliğe sahip bireyler yetiştirmektir. Bu kapsamda, 2018 YYB dersi öğretim programında da teknolojiye daha fazla vurgu yapılmalıdır. Örneğin, dijital hikaye hazırlamaya yönelik kazanımlara programda yer verilebilir. Ders kapsamında hazırlanacak olan dijital hikayeler aynı zamanda öğrencilerin yaratıcı yazma becerilerine de katkı sağlayacaktır. Uslu (2019) tarafından yapılan çalışmada da dijital hikayelerin öğrencilerin yaratıcı yazma becerilerini olumlu yönde etkilediği belirlenmiştir.

Öğretmenlerden elde edilen görüşler incelendiğinde; öğretmenlerin YYB dersine yönelik olarak daha çok sonuç odaklı değerlendirme yöntemlerini kullandıkları belirlenmiştir. Öğretmenlerin ders kapsamında kullandıkları ölçme araçları incelendiğinde ise daha çok yazılı sınavı tercih ettikleri belirlenmiştir. Bu bulgu Çarkıt ve Karadüz (2015) tarafından yapılan çalışmada elde edilen bulgularla benzerlik göstermektedir. Çarkıt ve Karadüz (2015) tarafından yapılan çalışmada da öğretmenlerin yönetmelikte zorunlu tutulan yazılı sınavlar aracılı̆ı̆ ile öğrencilerin yazma becerilerini değerlendirdikleri belirlenmiş̧ir. 2018 programında özellikle öz ve akran değerlendirme etkinliklerine yer verilmesi önerilmektedir. Fakat yapılan çalışmada, öğretmenlerin hiçbirinin öz değerlendirmeyi derslerinde kullanmadıkları; akran değerlendirmeyi ise sadece iki öğretmenin kullandığı tespit edilmiştir. 2018 YYB dersi öğretim programının süreç temelli olmasına karşın öğretmenlerin sonuç odaklı ölçme araçlarını tercih etmelerinin programın etkinliğini olumsuz yönde etkileyeceği söylenebilir.

Araştırma kapsamında, elde edilen bir diğer önemli bulgu ise öğretmenlerin büyük çoğunluğunun YYB dersi için belirlenen süreyi yeterli bulmadıklarıdır. 2018 YYB programında da yazma becerisinin yavaş gelişen bir beceri olduğu özellikle vurgulanmıştır. Dolayısıyla da öğrencilerin yazma becerilerinin geliştirilmesi için onlara yeterli sürenin verilmesi gerekmektedir. Tağa ve Ünlü de (2013) yaptıkları çalışmada, benzer bir bulguya ulaşmış ve yazma eğitiminde programdan kaynaklanan sorunların ilki olarak süre yetersizliğini göstermiştir. Öğrencilere yazma etkinlikleri için yeterli süre verilmediğinde ise bu durum öğrencilerde kaygı oluşmasına neden olabilir. Nitekim Karakoç Öztürk 
(2012) tarafından yapılan çalışmada, yazma etkinlikleri için kendilerine yeterli süre verilen öğrencilerin kaygı düzeylerinin yeterli süre verilmeyen öğrencilere göre daha düşük düzeyde olduğu belirlenmiştir.

YYB dersi öğretim programının uygulanmasında karşılaşılan sorunlar incelendiğinde, bazı öğretmenler kendileri ve meslektaşlarına yönelik bir özeleştiride bulunmuşlar ve uygulamada karşılaşılan sorunlardan birisinin öğretmenlerin bu dersi verecek yetkinlikte olmamalarından kaynaklandığını belirtmiştir. Bu durum üzerinde durulması gereken önemli bir noktadır. Çünkü bir eğitim programının etkili bir şekilde uygulanabilmesi o programın uygulayıcıları olan öğretmenlere bağlıdır. Dersin öğretmeni o derse yönelik gerekli yeterliliklere sahip olmadığında; program ne kadar etkili hazırlanmış olursa olsun hiçbir zaman programda yer alan hedeflere ulaşılamaz. Bu kapsamda, 2018 YYB dersi öğretim programının da etkili bir şekilde uygulanabilmesi için öncelikle bu dersi verecek olan öğretmenlerin yazma becerisi açısından belli bir yetkinliğe ulaşmaları gerekmektedir. Bu yetkinlik ise öğretmenlerin örgün eğitimde aldıkları dersler veya hizmet içi eğitim ile sağlanabilir. Yıldııım Bilgili ve Kana'ya (2018) göre, Türkçe öğretmeni adaylarının yazma becerisine yönelik aldıkları dersler çok sınırlıdır ve öğretmen adayları kendi istekleri ile yazma becerisine yönelik herhangi bir eğitim almamaktadır. Ürün Karahan (2017) tarafından yapılan çalışmada ise Türkçe öğretmeni adaylarının yazma becerisine yönelik kaygı düzeylerinin yüksek olduğu ve kendilerini yazma becerisi açısından yetkin görmedikleri belirlenmiştir. Bu doğrultuda, Türkçe öğretmenliği bölümünün lisans programına yazma becerisine yönelik farklı derslerin eklenmesi önerilebilir. Örneğin; bu derslerden birisi yaratıcı yazmaya yönelik olabilir. Yıldırım Bilgili ve Kana (2018) tarafından Türkçe öğretmeni adaylarıyla yapılan çalışmada, yaratıı yazmaya yönelik yapılan etkinliklerin öğretmen adaylarının yazma becerilerini artırdığı ve yazma becerisine yönelik tutumlarını olumlu yönde değiştirdiği belirlenmiştir. Tok ve Ünlü’ye (2014) göre ise öğretmenler öğrencilerin yazma becerisini geliştirici yöntem ve teknikler açısından yeterli bilgiye sahip değildir ve bu durum da öğretmenlerin bu derse ayrılan süreyi başka çalışmalar için kullanmalarına yol açabilir. Öğretmenleri yazma becerisi açısından yeterli bilgi ve beceri düzeyine ulaştırabilmenin yollarından birisi öğretmenlere verilecek kaliteli hizmet içi eğitimlerdir. Kaliteli denmesinin sebebi çalışmada bazı öğretmenlerin verilen hizmet içi eğitimleri kalitesini yetersiz bulmalarıdır. Bümen, Ateş, Çakar, Ural ve Acar'a (2012) göre maalesef Türkiye'de öğretmenlere yönelik düzenlenen mesleki gelişim programları, öğretmenlerin gelişimine herhangi bir katkı sağlamamakta ve sadece mecburiyetten dolayı gerçekleştirilmektedir. Bu nedenle de yapılacak hizmet içi eğitimlerin öncelikle öğretmenlerin yazma becerisine katkı sağlayacak nitelikte olması gerekmektedir. Yapılan çalışmada öğretmenler, 2018 programının en zayıf yönü olarak programın öğretmenlere yeteri kadar kılavuzluk edememesini göstermektedir. 2018 programında, 2012 programındaki öğretim programı uygulama kılavuzunun da yer almadığı düşünüldüğünde, bu eğitimlerin önemi daha da artmaktadır. Bu eğitimlerde, öğretmenlerin yazma becerisine yönelik olumlu tutum kazanmalarını sağlayacak etkinliklere de yer verilebilir. Çünkü Beydoğan'a (2012) göre, yazma etkinliklerinden hoşlanmayan bir öğretmenden öğrencilerinin yazma becerilerini geliştirmesi de beklenemez.

YYB dersi öğretim programına ilişkin öğretmenlerin uygulamada karşılaştıklarını belirttikleri sorunlardan birisi de öğrencilerin yazma etkinliklerine yönelik istek ve motivasyonlarının düşük olmasıdır. Yine öğretmenlerin bir kısmı, öğrencilerin yazma etkinliklerine yönelik ilgilerinin düşük olmasını programın zayıf yönü olarak görmektedir. Öğrencilerin yazma etkinliklerine yönelik ilgi ve motivasyonlarının düşük olmasının nedeni mevcut ulusal sınav sisteminden kaynaklanıyor olabilir. Yapılan çalışmada da öğretmenlerin bir kısmı, 2018 programının uygulanmasında karşılaşılan sorunlardan birisinin de mevcut sınav sistemi olduğunu belirtmiştir. Bilindiği üzere Türkiye'de gerek liselere gerekse de yükseköğretime girişte çoktan seçmeli testlere dayalı bir sınav sistemi uygulanmaktadır. Aşılıoğlu ve Özkan'a (2013) göre, mevcut sınav sisteminden dolayı testlere ağırlık verilmesi yazma etkinliklerine yeterli zamanın ayrılmamasına neden olmakta ve bu durum da öğrencilerin yazma becerilerinin gelişimini olumsuz yönde etkilemektedir. Öğrencilerin yazma becerilerinin gelişememesi ise onların yazma etkinliklerine yönelik kaygılar duymasına neden olabilir. Aşılığlu ve Özkan'a (2013) göre de ulusal sınav sisteminin çoktan seçmeli testlere dayalı olması öğrencilerde yazma etkinliklerine yönelik kaygılar oluşmasına neden olabilir. Yılmaz (2019) tarafından yapılan çalışma da bu görüşü desteklemektedir. Yılmaz (2019) tarafından yapılan çalışmada, 5. sınıftan itibaren öğrencilerin yazma becerisine yönelik kaygılarının sınıf düzeyi arttıkça yükseldiği ve 8 . sınıf 
öğrencilerinin daha çok test çözmeye ağırlık vermesinden dolayı yazma etkinlerine fazla zaman ayırmadıkları belirlenmiştir. Bu durumun da öğrencilerin 8. sınıf sonunda iyi bir liseyi kazanmak için girecekleri teste dayalı ulusal sınavdan kaynaklandığı söylenebilir. Aşılıoğlu ve Özkan’a (2013) göre, 8. sınıf öğrencilerinin 7. sınıf öğrencilerine göre yazma etkinlerine yönelik taşıdıkları kaygının daha yüksek olmasının nedeni 8. sınıf sonunda girecekleri sınava ilişkin başarı beklentisinin oluşturduğu kaygıdan kaynaklı olabilir. Dolayısıyla ulusal sınav sisteminin teste dayalı olması, YYB dersi öğretim programının uygulanma sürecini de olumsuz yönde etkilemektedir. Tok ve Ünlü (2014) tarafından yapılan çalışmada da ortaokul öğretmenleri, ulusal sınav sisteminin teste dayalı olmasının yazma becerisi için olumsuz bir durum oluşturduğunu belirtmiştir.

Araştırmada, öğretmenlerle yapılan görüşmeler sonucunda, YYB dersi öğretim programında karşılaşılan sorunların sadece yazma becerisinden kaynaklı olmadığı, öğrencilerin sahip oldukları okuma becerisinden kaynaklı sorunların da YYB programının uygulanma sürecini olumsuz yönde etkilediği belirlenmiştir. Yapılan çalışmada, öğretmenler, öğrencilerin okuma alışkanlıklarının olmayışının yazma etkinliklerini de olumsuz yönde etkilediğini belirtmiştir. Tağa ve Ünlü (2013) tarafından yapılan çalışmada da bu çalışmaya benzer bulgular elde edilmiştir. Tağa ve Ünlü (2013) tarafından yapılan çalışmada, yazma etkinliklerini olumsuz yönde etkileyen öğrenciden kaynaklanan sorunların başında öğrencilerin okuma alışkanlığının olmayışı gelmektedir. Bolat (2019) tarafından yapılan çalışmada ise öğrencilerin okuma alışkanlıkları ile yazma etkinliklerine yönelik öz yeterlilik düzeyleri arasında orta düzeyde bir ilişkinin olduğu tespit edilmiştir. Okuma alışkanlığı olmayan öğrencilerin yazma etkinliklerine yönelik duyacakları öz yeterlilik düzeyinin düşük olması ise öğrencilerin yazma etkinliklerine yönelik kaygılar duymasına neden olabilir. Alanyazında yapılan çalışmalar da bu görüşü doğrular niteliktedir. Yaman (2010) tarafından yapılan çalışmada, ayda 3-4 kitap okuyan öğrencilerin yazma etkinliklerine yönelik duydukları kaygı düzeylerinin hiç kitap okumayan öğrencilere göre daha düşük olduğu sonucuna ulaşılmıştır. Yine Temel ve Katrancı (2019) tarafından 4. sınıf öğrencileriyle yapılan çalışmada, öğrencilerin okudukları kitap sayısı arttıkça, onların yazma etkinliklerine yönelik tutumlarının olumlu yönde değiştiği ve yazma etkinliklerine yönelik kaygı düzeylerinin azaldığı belirlenmiştir. Ayrıca Yaman'a (2010) göre, okuma becerisi yazma becerisi için bir ön hazırlıktır. Bu doğrultuda da öğrencilerin yazma becerilerini daha etkin kazanabilmeleri için öncelikle okuma alışkanlığı kazanmaları ve okuma becerilerini geliştirmeleri gerektiği söylenebilir. Yapılan bu araştırmada da öğretmenlerin bir kısmı "Okuma becerileri" dersinin YYB dersinden önce verilmesini önermektedir. Dolayısıyla da Türkçe eğitimine ilişkin seçmeli derslerin verileceği sınıf düzeyleri planlanırken, bu durum göz önünde bulundurulabilir ve öğrencilerin YYB dersini "Okuma becerileri" dersini aldıktan sonra almalarına özen gösterilebilir.

Öğretmenlerin YYB programına yönelik görüşleri doğrultusunda, öğretmenlere kılavuzluk edecek bir etkinlik kitabının oluşturulması, dersle ilgili materyallerin okullara temin edilmesinin sağlanması, dersi seçecek öğrenciler için belli bir kontenjanının belirlenmesi, seçmeli derslerin tercihinin öğretmenler tarafından yapılması ve de öğrencilerin seçmeli dersleri tercih etmeden önce ders hakkında bilgilendirilmesi YYB dersine yönelik yapılabilecek diğer önerilerdir. Yine öğretmenlerin görüşleri doğrultusunda, Türkçe eğitimine yönelik ortaokullarda ders havuzu zenginleştirilerek "Diksiyon", "Drama" ve "Konuşma teknikleri" gibi dersler de seçmeli ders havuzuna eklenebilir. Ayrıca YYB dersine yönelik programın diğer paydaşlarından öğrenci, idareci ve velilerden de görüşlerin alındığı çalışmalar yapılabilir. Yine bu derse yönelik yapılan bu çalışmanın bir benzeri "Okuma becerileri", "iletişim ve sunu becerileri" ve "Yaşayan diller ve lehçeler" gibi Türkçe eğitimine yönelik diğer seçmeli dersler için de gerçekleştirilebilir.

\section{Kaynaklar}

Aktaş, Ş. ve Gündüz, O. (2015). Yazılı ve sözlü anlatım okuma-dinleme-konuşma-yazma. Ankara: Akçağ Yayınları.

Afrin, N. (2014). Reasons of problems in writing class in the tertiary level of Bangladesh. International Journal of Humanities and Social Science Invention, 3(11), 41-48.

Aşılıoğlu, B. ve Özkan, E. (2013). Ortaokul öğrencilerinin yazma kaygılarının bazı değişkenler açısından incelenmesi: Diyarbakır örneği. The Journal of Academic Social Science Studies, 6(6), 83-111. 
Bahşi, N. ve Sis, N. (2019). Ortaokul öğrencilerinin cümle, paragraf ve metin oluşturma düzeyi üzerinde etkili olan değişkenler. Ana Dili Eğitimi Dergisi, 7(3), 553-573.

Baş, G. ve Şahin, C. (2013). Illköğretim öğrencilerinin yazma eğilimlerinin farklı değişkenler açısından incelenmesi. Sakarya University Journal of Education, 3(1), 32-42.

Becel, A. (2013). Bilişim teknolojileri ekseninde yazarlık ve yazma becerileri dersine yönelik bir değerlendirme. Turkish Studies, 8(3), 61-81.

Beydoğan, H. Ö. (2012). Öğretmenlerin yazılı anlatıma ilişkin geliştirdikleri düşünce ve eğilimler, Ahi Evran Üniversitesi Kırşehir Eğitim Fakültesi Dergisi 13(2), 177-204.

Bolat, E. (2019). Illkokul 4. sınıf öğrencilerinin okuma alıskanlıkları ile yazma öz yeterlilikleri arasındaki ilişki-ı̆̆dır ili örneğii-. Ankara: Gazi Üniversitesi, Yayımlanmamış Yüksek Lisans Tezi.

Bümen, N. T., Ateş, A., Çakar, E., Ural, G. ve Acar, V. (2012). Türkiye bağlamında öğretmenlerin mesleki gelişimi: sorunlar ve öneriler. Milli Eğitim Dergisi, 42(194), 31-50.

Calp, M. (2010). Özel eğitim alanı olarak Türkçe öğretimi. Ankara: Nobel Yayıncılık.

Çarkıt, C. ve Karadüz, A. (2015). Ortaokul yazarlık ve yazma becerileri dersi bağlamında yazma becerisi öğretimi üzerine öğretmen görüşleri. Bartın Üniversitesi Eğitim Fakültesi Dergisi, 4(2), 364-381.

Defazio, J., Jones, J., Tennant, F. \& Hook, S.A. (2010). Academic literacy: the importance and impact of writing across the curriculum-a cases tudy. Journal of the Scholarship of Teaching and Learning, 10(2), 34-47.

Deniz, E. (2017). Yedinci sınıf öğrencilerinin dil bilgisi, kelime bilgisi ve okuduğunu anlama düzeyleri ile yazma becerileri arasındaki ilişki. Malatya: İnönü Üniversitesi, Yayımlanmamış Doktora Tezi.

Durga, S. S. \& Rao, C. S. (2018). Developing Students' Writing Skills in English-A Process Approach. Journal for Research Scholars and Professionals of English Language Teaching, 6(2), 1-5.

Glesne, C. (2012). Nitel araştırmaya giriş. (Çeviri Editörleri: A. Ersoy ve P. Yalçınoğlu). Ankara: Anı Yayıncılık.

Gündüz, O. ve Şimşek, T. (2016). Uygulamalı yazma eğitimi. Ankara: Grafiker Yayınları.

Kaleağası, i. (2009). Yaratıcı okuma-yaratıcı yazma çalışmalarının yaratıcı okuma, okuduğunu anlama, yazma ve yaratıcı yazma erişişine etkisi. Adana: Çukurova Üniversitesi, Yayımlanmamış Yüksek Lisans Tezi.

Kaleli Yılmaz, G. (2015). Durum çalışması. M. Metin (Ed.), Kuramdan uygulamaya eğitimde bilimsel araştırma yöntemleri (ss. 261-285). Ankara: Pegem Akademi Yayıncılık.

Karakoç Öztürk, B. (2012). İlköğretim ikinci kademe öğrencilerinin yazma kaygılarının çeşitli değişkenler açısından incelenmesi. Çukurova Üniversitesi Sosyal Bilimler Enstitüsü Dergisi, 21(2), 59-72.

Karatay, H. (2011). 4+ 1 planlı yazma ve değerlendirme modelinin öğretmen adaylarının yazılı anlatım tutumlarını ve yazma becerilerini geliştirmeye etkisi. Turkish Studies, 6(3), 1029-1047.

Kasap, D. (2019). Yedinci sınıf öğrencilerinin dil bilgisi, kelime bilgisi ve okuduğunu anlama düzeyleri ile yazma becerileri arasındaki ilişki. Denizli: Pamukkale Üniversitesi, Yayımlanmamış Doktora Tezi.

Kasten, W. C. ve Yıldırım, K. (2013). Okuma ve yazma eğitimi: tek başıma öğrenemem ki. Ankara: Pegem Akademi Yayıncilık.

MEB (2012). Ortaokul ve imam hatip ortaokulu yazarlık ve yazma becerileri dersi (5, 6, 7 ve 8. sınıflar) öğretim programı. Ankara: Milli Eğitim Bakanlığı.

MEB (2018). Yazarlık ve yazma becerileri dersi ögretim programı (ortaokul ve imam hatip ortaokulu 5, 6, 7 ve 8. sınıflar) Ankara: Milli Eğitim Bakanlığı.

Miles, M. B. \& Huberman, A. M. (1994). An expanded sourcebook qualitative data analysis. London: Sage Publications.

Maltepe, S. (2006). Yaratıcı yazma yaklaşımı açısından Türkçe derslerindeki yazma süreçlerinin ve ürünlerinin değerlendirilmesi. Ankara: Ankara Üniversitesi, Yayımlanmamış Doktora Tezi.

Oshchepkova, T. \& Alkhaldi, A. A. (2018). How to develop writing skills in a foreign language?. European Journal of Foreign Language Teaching, 3(4), 174-185.

Özdemir, S. ve Çevik, A. (2018). Yaratııı yazma çalışmalarının yazmaya yönelik tutuma ve yaratıcı yazma başarısına etkisi. Inönü Üniversitesi Eğitim Fakültesi Dergisi, 19(2), 141-153. 
Özonat, Z. ve Sis, N. (2016). Yazarlık ve yazma becerileri dersi üzerine bir araştırma. Turkish Studies, 11(3). 1879-1902.

Sadiku, L. M. (2015). The importance of four skills reading, speaking, writing, listening in a lesson hour. European Journal of Language and Literature, 1(1), 29-31.

Susar Kırmızı, F. ve Beydemir, A. (2012). İlköğretim 5. sınıf Türkçe dersinde yaratıcı yazma yaklaşımının yazmaya yönelik tutumlara etkisi. Ahi Evran Üniversitesi Kırşehir Eğitim Fakültesi Dergisi, 13(3), 319-337.

Tağa, T. ve Ünlü, S. (2013). Yazma eğitiminde karşılaşılan sorunlar üzerine bir inceleme. Turkish Studies, 8(8). 1285-1299.

Temel, S., ve Katrancı, M. (2019). İlkokul öğrencilerinin yazıı ınlatım becerileri, yazmaya yönelik tutumları ve yazma kaygıları arasındaki ilişki. Avrasya Uluslararası Araştırmalar Dergisi, 7(17), 322-356.

Temur, T. (2001). ilköğretim 5. sınıf öğrencilerinin yazılı anlatım beceri düzeyleri ile okul başarıları arasındaki ilişki. Ankara: Ankara Üniversitesi, Yayımlanmamış Yüksek Lisans Tezi.

Tok, M. ve Ünlü, S. (2014). Yazma becerisi sorunlarının ilkokul, ortaokul ve lise öğretmenlerinin görüşleri doğrultusunda karşılaştırılmalı olarak değerlendirilmesi. Elektronik Sosyal Bilimler Dergisi, 13(50), 73-95.

Tok, M. ve Potur, Ö. (2015) Yazma eğitimi alanında yapılan akademik çalışmaların eğilimleri (2010-2014 yılları). Ana Dili Eğitimi Dergisi, 3(4), 1-25.

Ungan, S. (2007). Yazma becerisinin geliştirilmesi ve önemi. Dumlupınar Üniversitesi Sosyal Bilimler Enstitüsü Dergisi, 23(2), 461-472.

Uslu, A. (2019). Iş̧birlikli dijital hikaye anlatımının ilkokul 4. sınıf öğrencilerinin yaratıcı yazma ve sosyal duygusal öğrenme becerilerine etkisi. Manisa: Manisa Celal Bayar Üniversitesi, Yayımlanmamı̧ Yüksek Lisans Tezi.

Ürün Karahan, B. (2017). Türkçe öğretmeni adaylarının yazma kaygıları ile yazma alışkanlıkları arasındaki ilişki. Insan ve Toplum Bilimleri Araştırmaları Dergisi, 6(5). 3065-3075.

Yakıcı, A., Yücel, M., Doğan, M. ve Yelok V. S. (2006). Yazılı anlatım. Ankara: Gazi Kitabevi.

Yaman, H. (2010). Türk öğrencilerinin yazma kaygısı: ölçek geliştirme ve çeşitli değişkenler açısından yordama çalışması, International Online Journal of Educational Sciences, 2(1), 267-289.

Yıldııı, A. ve Şimşek, H. (2013). Sosyal bilimlerde nitel araştırma yöntemleri. Ankara: Seçkin Yayıncılık.

Yıldırım Bilgili, G. ve Kana, F. (2018). Yaratıcı yazma etkinliklerinin Türkçe öğretmeni adaylarının yazma becerisine etkisi. Akdeniz Eğitim Araştırmaları Dergisi 12(26), 544-561.

Yılmaz, N. (2019). Ortaokul öğrencilerinin yazma kaygısı düzeyleri ve nedenlerinin belirlenmesi (Elazığ örneği). Malatya: İnönü Üniversitesi, Yayımlanmamış Yüksek Lisans Tezi.

Younes, Z. \& Albalawi, F. S. (2015). Exploring the most common types of writing problems among English language and translation major sophomore female students at Tabuk University. Asian Journal of Basic and Applied Sciences, 3(2), 7-26.

\section{Introduction}

\section{Extended Abstract}

In 2018, the 2012 curriculum of the authorship and writing skills (AWS) course was revised and the 2018 AWS course curriculum was prepared. In this study, the 2018 curriculum was taken as a basis. In the 2018 AWS curriculum, writing skills are seen as a process as in the 2012 AWS curriculum.

The effectiveness of the 2018 AWS curriculum in providing students with writing skills can only be determined by evaluating the curriculum. The most valuable opinions about the effectiveness of curriculum can be obtained from teachers who are the curriculum's implementers. In this research, it is aimed to evaluate the 2018 AWS curriculum in line with the teachers' opinions. In the literature, there is no study for the current 2018 AWS curriculum. Therefore, this study is expected to contribute to the literature. In addition, with this research, it is considered that the deficiencies identified for the 2018 AWS curriculum in line with the opinions obtained from teachers will be a valuable data source for the curriculum to be updated in the following years. 


\section{Method}

In this research, the research model was designed as a case study, which is one of the qualitative research methods, since it was aimed to determine the teachers' opinions on the current 2018 AWS curriculum.

The study group consists of 15 Turkish teachers working in 4 different provinces of Turkey. The teachers whose opinions were taken were determined by using maximum variation sampling method which is one of the purposive sampling methods.

In the research, a semi-structured interview form was used to determine the opinions of teachers about the 2018 AWS course curriculum.

In the analysis of the data obtained within the scope of the research, content analysis method was used.

\section{Result and Discussion}

One of the most important points that attract attention in the 2018 AWS course curriculum examined in the scope of the research is the lack of importance given to creativity in the curriculum. In the interviews with teachers, some of the teachers emphasized this situation. When the gains in the 2018 AWS course curriculum are examined, it is seen that the gains related to the creative writing skills of the students are not included in the curriculum.

One of the important findings obtained during the interviews with teachers is that teachers do not make much use of technology in the teaching-learning process for this course. Only one of the interviewed teachers stated that they had their students prepare digital books. However, in the digital era we live in, it is expected to take more advantage of technology for this course.

When the problems encountered in the implementation of the curriculum of the AWS course were examined, some teachers made a self-criticism for themselves and their colleagues and stated that one of the problems encountered in practice was that the teachers were not competent to give this course. In this context, for the effective implementation of the 2018 AWS course curriculum, the teachers who will give this course must first achieve a certain competency in terms of writing skills. This competence can be achieved through the courses that teachers take in formal education or inservice training.

One of the problems that teachers have encountered in practice regarding the AWS course curriculum is that students' interest and motivation towards writing activities are low. The reason for the low level of interest and motivation of students for writing activities may be due to the current national examination system. In the study, some of the teachers stated that one of the problems encountered in the implementation of the 2018 AWS curriculum was the existing examination system.

In line with the opinions of the teachers regarding the AWS curriculum, other suggestions for AWS curriculum are creating an activity book that will guide the teachers, ensuring that the materials related to the course are provided to the schools, determining a certain quota for the students who will choose the course, and making the choice of the elective courses by the teachers, informing the students about the course before choosing the elective courses. Again, in accordance with the opinions of teachers, the elective pool in Turkish secondary schools can be enriched by adding courses such as "Diction", "Drama" and "Speech techniques". In addition, studies in which the opinions of students, administrators and parents who are the other stakeholders of the curriculum are obtained can be made for this course. Also, study similar to study conducted for this course can be realized for other elective courses for Turkish language education such as "Reading skills", "Communication and presentation skills" and "Living languages and dialects". 


\section{Ek-1. Görüşme Soruları}

1. Yazarlık ve Yazma Becerileri Dersi Öğretim Programı'na yönelik hizmet içi eğitim aldınız mı? Cevap evet ise: Eğitimi yeterli buldunuz mu?

Cevap hayır ise: Sizce bu eğitime ihtiyaç var mı?

2. Yazarlık ve Yazma Becerileri dersi için programda belirlenen yeterlilik alanları ile ilgili düşünceleriniz nelerdir?

3. Yazarlık ve Yazma Becerileri dersi için programda belirlenen kazanımlar ile ilgili düşünceleriniz nelerdir?

4. Yazarlık ve Yazma Becerileri dersine yönelik öğretme-öğrenme sürecinde hangi yöntem ve teknikleri kullanıyorsunuz? Ne tür etkinlikler yapıyorsunuz?

5. Yazarlık ve Yazma Becerileri dersine yönelik ne tür bir değerlendirme yapıyorsunuz? Hangi ölçme araçlarını kullanıyorsunuz?

6. Yazarlık ve Yazma Becerileri Dersi Öğretim Programı́nın uygulanma sürecinde sizi zorlayan durumlar nelerdir?

7. Yazarlık ve Yazma Becerileri dersi için ayrılan süreyi yeterli buluyor musunuz?

8. Yazarlık ve Yazma Becerileri dersinin seçmeli ders olarak programda yer alması hakkındaki düşünceleriniz nelerdir?

9. Yazarlık ve Yazma Becerileri dersi dışında "Okuma Becerileri", "iletişim ve Sunu Becerileri”, Yaşayan Diller ve Lehçeler" seçmeli derslerinden hangisini vermek isterdiniz? Neden?

10. Türkçe eğitimine ilişkin başka hangi dersler seçmeli ders olarak verilebilir?

11. Sizce Yazarlık ve Yazma Becerileri Dersi Öğretim Programı'nın güçlü ve zayıf yönleri nelerdir?

12. Yazarlık ve Yazma Becerileri Dersi Öğretim Programı́nın daha etkili uygulanabilmesi için önerileriniz nelerdir? 